Review

\title{
Decision Support Systems in Construction: A Bibliometric Analysis
}

\author{
Muhammad Rashid Minhas * and Vidyasagar Potdar \\ School of Management, Curtin University, Perth 6102, Australia; v.potdar@curtin.edu.au \\ * Correspondence: muhammad.minhas@postgrad.curtin.edu.au; Tel.: +61-469192823
}

Received: 19 January 2020; Accepted: 20 April 2020; Published: 8 June 2020

\begin{abstract}
In recent years, the use of decision support systems for selecting sustainable construction materials in the building and commercial construction projects has received a great deal of attention. This paper reports an in-depth and systematic bibliometric analysis of the literature using Decision Support Systems (DSSs) for its construction, based on the papers published during the period from 2000 to 2016. The data were collected from two major databases, Web of Science (WoS) and Scopus, which included 2185 and 3233 peer reviewed articles, respectively. The analysis includes a general bibliometric analysis (publications output, country-wise research output, authorship, and collaboration patterns of these published articles). It also includes a citation analysis (keywords, most cited keywords, organizations, most cited articles, and average citations per article) and a network analysis (authors and countries). Overall, this study provides bibliometric insights and future research directions for researchers and practitioners who use DSSs.
\end{abstract}

Keywords: decision support system; construction industry; multi-criteria decision making tools; building information modelling (BIM); sustainable development; artefact modelling; retrofitting; bibliometric analysis

\section{Introduction}

The construction sector has evolved over time by adopting the latest technologies for different phases of construction, including design, execution, and operation. Each phase has its own importance-e.g., selecting the right design parameters is considered the backbone of a construction activity. Selecting the correct construction materials to satisfy design and operational specifications also has unique value. Technological shifts have made the construction process more demanding, thereby also making the jobs of the technical personnel more challenging.

Information technology is playing a critical role in making this job even more precise, accurate, and fast. By offering innovative information systems, such as neural networks [1], decision support systems [2], and expert systems [3], the work of technical stakeholders and managers has become very simple and fairly accurate.

From the very beginning, design software such as AutoCAD [4], Building information modelling (BIM) [5,6], Structural analysis program SAP 2000 [7], Extended 3D (three dimensional) analysis of building system (Etabs) [8], Revit building information modelling software [9] has injected a new spirit into the modern construction process. Similarly, PrimaveraTM [10] and BuildsoftTM [11] are good for use in construction execution, control, and monitoring systems. The rapid growth in the construction sector has made the construction manager/decision maker's job more hectic and tedious. Information technology in the form of decision support systems is now helping to make this job easier, more reliable, and more accurate.

In recent decades, many scientific articles were published in the field of decision support systems in construction, studying, for example, optimal cost analysis [12,13], multi-objective optimization [14,15], 
building energy performance [16,17], project management and green buildings, [18,19], building information modelling [20,21], and virtual building design [22]. These efforts were made to determine the best combination of energy management systems for cost effectiveness [23].

The construction sector is one of the largest consumers of energy; hence, significant efforts are being made to monitor energy consumption using a variety of methods, such as life cycle analysis (LCA) [24,25], retrofitting buildings [26-28], and photovoltaics [29,30]. The LCA approach is applied when buildings have different functions, sizes, materials, and positions. These methods are based on the ISO 14040 standards with different scopes, aims, and limitations [31]. Retrofitting the façade is also being used to solve this issue of energy saving and management [27].

Architects and engineers now play a critical role in the design stage and incorporate design features that ensure low energy buildings. This approach is now widely used for energy conservations in buildings, which paves the way toward the adoption of the latest building technologies, such as double faced ventilation, improved cooling and heating of the building, integrated photovoltaics, and green facades [32].

Construction design and management are central to decision making in construction. Cost benefit analysis is one of the best suited approaches to make informed decisions [33]. Time, cost, and quality are important criteria during the planning phase of construction. An evidential reasoning approach is often used to settle these issues during the scheduling of construction projects [2].

However, a thorough bibliometric analysis of the literature that systematically studies the field and determines its research growth and trends over the last two decades has not be published.

A bibliometric analysis is "a set of mathematical and statistical methods used to analyse and measure the quantity and quality of the books, articles and other forms of publications" [34]. This is also described by Henk F. Moed as a "subfield of quantitative science and technology studies aimed to construct the indicators of research performance from a quantitative research analysis of scientific-scholarly documents" [35].

There are three types of bibliometric indicators: "(1) quantity indicators, which measure the productivity of a particular researcher, (2) quality indicators, which measure the quality (or performance) of a researcher's output, and (3) structural indicators, which measure the connections between publications, authors, and areas of research" [35].

At times, it is difficult to develop a literature analysis for emerging technologies because there are no relevant historical data available. In this case, a bibliometric analysis is the tool used to find the emerging technologies discussed in different articles [36].

The basic idea behind a bibliometric analysis is to explore the insights of a specific topic by conducting a statistical data analysis and content analysis to find future research directions. Such an in depth analysis provides a better understanding of the quantitative, qualitative, and structural aspects of the literature by investigating the total number of articles published per year, the annual growth, the doubling time, the top contributing countries, the most commonly occurring keywords, the most well-known researchers, most cited articles, average citations, international collaborations, etc.

The key objectives of this paper are to (1) conduct a quantitative analysis of the literature in the area of decision support systems for construction (e.g., identifying major contributing countries, authors, institutes, etc.), (2) conduct a qualitative analysis of the literature (e.g., keyword analysis, degree distributions, etc.), (3) conduct a structural/network analysis of the literature (e.g., citation analysis and complex network analysis), (4) develop a taxonomy / classification of the literature based upon the content analysis, and (5) identify the latest research outcomes in this field.

The rest of the paper is organized as follows: the "Introduction" in Section 1 outlines the basics of the research, Section 2 (Literature Review) provides a complete picture of research progress up to the year 2016. Section 3 (Data Collection and Methodology) explains the complete process of data collection and research used in this study. Section 4, "Results and Discussion", explains the key findings, analysis outcomes, and future steps. Section 5, "New and Promising Areas of Research", demonstrates 
that bibliometric analysis is an essential and thought-provoking new technique in information science. Section 5 is the Conclusion, which describes the usefulness and benefits of the study.

\section{Literature Review}

Construction is one of the key sectors used to assess the progress of any nation. It represents development in terms of overall GDP [37], infrastructure betterment [38], and overall improvement in the living standards of common people. Modern ideas of orientation [39], sustainable construction practices [40], green buildings, and energy management [18] have reached new heights in terms of their standards and level of adoption within our society.

The decision-making process is so crucial in construction that it determines the project's success or failure. Most of the activities in this process are considered to be conflicting in nature, which problematizes overall decision making and management [41]. Some of the key focus areas during the decision making process are energy conservation [42] and energy management [43]. Indeed, $20 \%$ to $30 \%$ of energy can be saved by optimizing the operations and management during the construction phase $[44,45]$, without changing the building's structure or the hardware configuration of the energy supply system [46].

In developed nations, more than $40 \%$ of energy (electricity, gas, and water) is consumed by the building sector, which raises serious concerns about how to make buildings more energy efficient [47]. The energy conservation of buildings is also a major influential criterion to consider when developing the idea of precise and profitable construction. Energy consumption is a critical area, as more than $70 \%$ of electricity is consumed by the building sector.

Energy retrofitting reconciles this issue to a certain extent [48]. Energy retrofitting refers to the physical or operational change of a building's energy consuming equipment. It requires upgrading or replacement of an old building system with new and improved energy saving technology and processes $[49,50]$, such as replacing single glazed windows with double glazed windows.

A hybrid decision support system should be used when renovating offices or building to improve energy performance because each single technique has its own limitations [16]. The system dynamics method is also used as a tool for decision making in buildings. As diverse technical disciplines are involved in building and construction (e.g., architecture; structural, mechanical, and electrical engineering; land development; security etc.), the actual performance of the building cannot be judged by a single metric. Thus, a robust and hybrid method needs to be adopted. This can be accomplished using a system dynamics approach by modelling it as a feedback system of its subsets [8].

Data mining is also used for decision support systems. Data mining is the process of extracting previously unknown information from textual data. Data and knowledge make up the resources of such a system and are a key link during decision making [51].

Uncertainty and sensitivity analyses are often used to validate the simulation tools used for the design of buildings to increase energy performance. This is required to evaluate the reliability of the simulation and measurement of uncertainty to improve the building's design [52]. Uncertainty assessment plays a very critical role in the design and decision making processes [53].

During the operational phase of the building, maintenance is the primary resource consuming factor. Corrective, preventive, and condition-based maintenance can solve this issue [54]. Alternative techniques and methods are also used extensively to improve construction effectiveness. Multi attribute decision making techniques can be used to optimize this aspect [55].

The estimate at completion (EAC) approach indicates the final cost to produce an exact comparison between the estimated construction cost and the actual cost. This greatly helps to make accurate decisions for subsequent construction projects [56]. Research in modelling and simulation in the construction industry allows decision makers to obtain future insight into the automated project planning and control of construction projects [57].

Building sustainability is also an emerging concept used in the construction world. Sustainability assessment requires a large information data set, as well as many parameters and uncertainties. 
Multi-criteria decision analysis (MCDA) has been considered an appropriate method to carry out performance evaluation due to its flexibility [58]. The assessment process infers the presence of tools, processes, specifications, procedures, and methodologies for steady performance under the umbrella of sustainability [59].

Moreover, green roofing has been a topic of interest for the last two decades. The number of relevant publications has increased dramatically in this time period. USA and Europe were the main participants in this research direction [60]. Vernacular construction is more concerning in Europe due to its limited infrastructure development and altered land conditions. Different materials and construction methods have been adopted to better understand the recovery of Spanish bioclimatic architecture [61].

Overall, there are a number of research directions within the broad umbrella of decision support systems for construction. These directions include energy conservation, energy management, operations and management, energy retrofitting, uncertainty and sensitivity analysis, maintenance, estimating project costs, future project costs, and green roofing.

To understand the progress in this field, a systematic analysis of the literature using a bibliometric methodology is required. When we studied the literature, we found some previous related works in this field. For example, Ying Chen found that prefabrication can offer a substantial opportunity to maintain sustainability but that the decision to apply a method is largely based upon personal preference rather than available datasets [62].

Shaddy Attia said that there is a need to develop a decision support system to integrate energy simulations into the early design of zero energy buildings [63]. Xiaodong developed a decision support system for strategic maintenance planning in wind farms. This decision support system is based upon two optimization models. One is the deterministic model used to find accurate failure rate data, and the second is the stochastic model, which is used to determine the failure rates with less certainty [64]. Igor studied the latest progress in heuristic based decision support systems to select alternate routes in a large-scale transportation transit system. He found that, normally, computer-based Decision Support Systems (DSSs) are good to use in computer analysis programs but difficult to implement in real-world problems. He developed a formal method using the Petri Net model [65].

A substantial amount of research has been undertaken in the last two decades on bibliometric studies in construction. For example, a bibliometric analysis was done by Ignacio regarding the evolution of construction and building technology. Ignacio's paper describes the evolution of the merits of various researchers and research institutes [66]. The current trends in solid waste management are discussed by Lie Yang. This topic has become very interesting due to limited resources, the exceptional increase in the world's population, rapid urbanization, and global industrialization [67]. Lior Blank investigated the directions in green roof research, which is a multi-disciplinary field of research. Green roofs provide more benefits than their alternatives (such as heat flux, vaporization, and insulation), except for aesthetics [60]. Energy efficient building renovations are discussed by Jonas. More than $30 \%$ of global gases are produced by the building sector. Thus, this sector requires the most efficient renovations to reduce this factor [68].

\section{Methodology}

Bibliometric analysis describes and analyses up to date research and provides guidance on future directions for researchers and practitioners. It aims at summarizing the latest progress in the field by investigating the literature in a quantitative manner. Some researchers find bibliometric analysis a useful tool to obtain comprehensive insight into specific research areas, while others seriously question the validity of this approach.

Giovanni Abramo noted that bibliometric analysis is much more reliable than peer review [69]. Rodrigo Costas stated that bibliometric indicators are very useful for developing research policy and monitoring technological activities [70]. Briger argued that this method is useful for recognizing candidate terms and organizing knowledge by relating scientific papers to their authors, thus indicating 
their relatedness and semantic differences [71]. Diana referred to this method as an unparalleled opportunity to take advantage of the rich information embedded in the written products of scientific research to determine the output and influence of funded scholars [72].

Conversely, some researchers have identified major disadvantages to this technique. Lutz Bornmann mentioned that percentiles and percentile ranking have limited use when there are the same number of citations for an article. The size of the reference set is always an important factor while setting up the classes for ranking [73]. The H-Index is another factor that has some issues in providing accurate facts and efficacy [74].

Overall, this method provides a vast canvas of knowledge from the micro level (institutes, researchers, and campuses) to the macro level (countries and continents) [75]. This technique can provide more information about the relationship between different research directions among various universities. Citation and content analysis represents the most widely used criteria that can (1) tell us about the citations and citation trends in a specific field of knowledge and (2) describe the direction of modern research by presenting the most widely used author keywords.

In this paper, we computed the following major trends: relative growth rate (RGR), doubling time (DT), collaboration index (CI), collaborative coefficient (CC), and international collaboration papers (ICP), with most productive institutes and authors under the headings of the (TP) and (TC) plots. The text analysis approach is also applied to determine the major research hot spots [76]. Frequency analysis is used to find the most commonly cited and most commonly occurring keywords. A topic density plot for the control terms is also developed to provide information on the major research trends in the field. Science mapping is carried out using the VOS viewer tool $[77,78]$.

\subsection{Data Sources and Collection}

This bibliometric analysis was conducted using selected journal articles specialized in the area of decision support systems in construction. These articles were accessed using the Scopus and Web of Science (WoS) databases. Access to these databases was provided by Curtin University, Australia. We performed a bibliometric citation and content analysis to obtain our research objectives.

A systematic approach was adopted when searching for articles using the following keyword: "Decision support system in construction". This search was restricted to the engineering, computer science, environmental science, decision science, soil science, applied energy, applied physics, and material science areas, since these fields are the most strongly related to construction and the multi-criteria decision making (MCDM) techniques used for decision support systems. Several other fields also appeared in the search results, such as medical science, management, agriculture, optics, ergonomics, internal relations, and many more, but they were excluded.

We further restricted our data collection only to articles, reviews, proceedings, and book chapters. Using this research strategy, we selected 3233 and 2185 articles from Scopus and WoS, respectively. Only articles published between 2000 and 2016 were selected in this study.

\subsection{Data Analysis Tool}

We used the VOS viewer as a tool to develop certain types of graphs (e.g., international collaborations and keyword density distribution). Further, we used NAILS (network analysis interface for literature studies) to sort the literature data into subjects, keywords, authors, citations, occurrences, affiliations, institutes, and locations [79].

Results and discussion:

In this section, the different parameters are computed to determine the various aspects of the literature, such as year-wise contribution during this timeframe, growth rate, doubling time, authorship and collaboration patterns, major publication areas, and the subject-wise distribution of research work. 


\subsection{Publication Output (2000 to 2016)}

The publication output is presented in Figure 1, which presents the annual number of publications in both Scopus and WoS under the heading "decision support system in construction". In the years 2000 and 2001, Scopus had 60 articles each, while WoS had 55 and 51 articles, respectively. The year 2002 showed good improvement, with 116 articles in Scopus and 72 in WoS. A dip occurred again in 2003 and 2004, but the publications have experienced an upward trajectory ever since. Notably, in 2015, the number of publications in WoS outranked that in Scopus. The year 2016 again showed the dominancy of Scopus articles (279) compared to those in WoS (171). Figure 1 shows that there was a segmental but continuous increase in the research being undertaken in the field of decision support systems in construction. Although there were some instances of a downward trend in the stipulated timeframe, the overall trend experienced an upward trajectory.

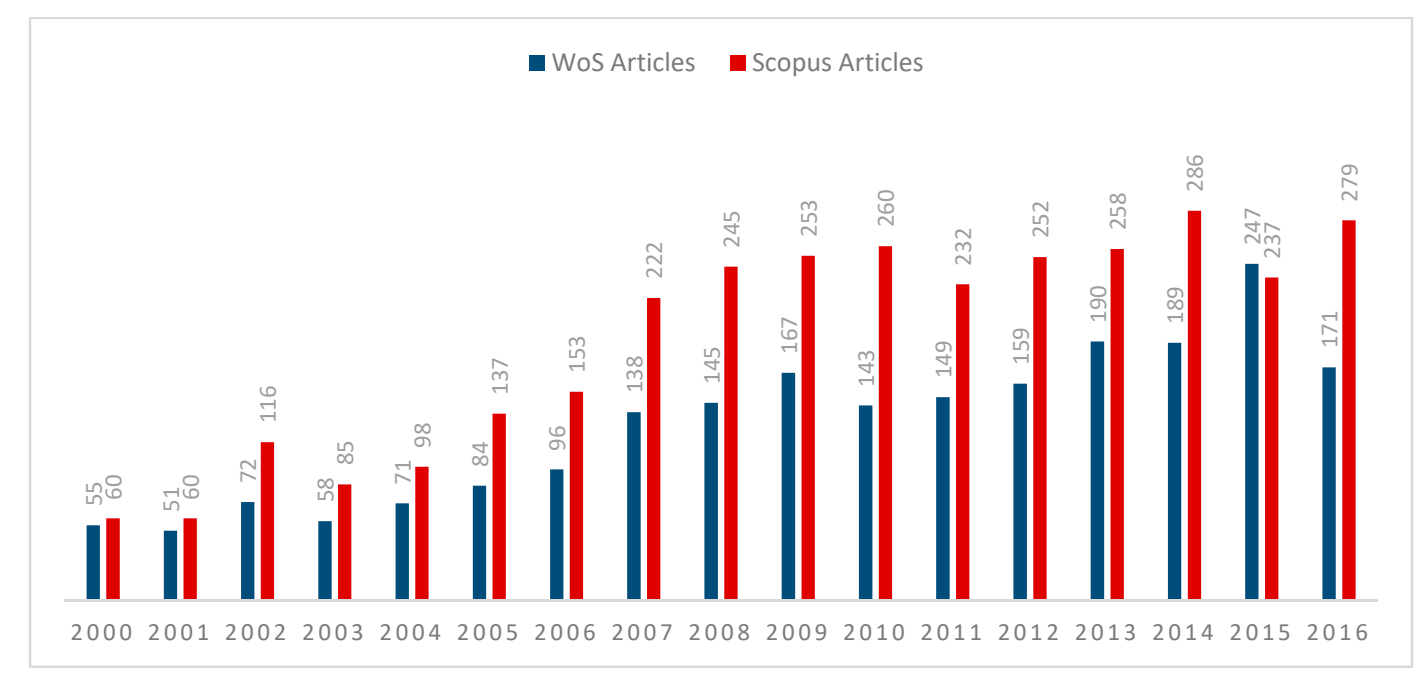

Figure 1. Annual publications in the Decision Support System research area in Scopus and Web of Science (WoS).

\subsection{Relative Growth Rate (RGR)}

The growth rate per annum was calculated to find the incremental trend of yearly output and the doubling time of the published articles, such as the time required to double the total number of articles. In both the databases, both of these parameters were calculated using the following formula [80]. This formula was used by Mahapatra [81] to find this parameter and its significance.

$$
\text { Relative Growth Rate }(\mathrm{RGR})=\ln \frac{\mathrm{CN}_{2}}{\mathrm{CN}_{1}}
$$

where $C N_{2}$ and $C N_{1}$ are the cumulative number of publications each year.

\subsection{Doubling Time (DT)}

The doubling time (DT) has a direct relationship with the relative growth rate (RGR). It gauges the time required to double the existing number of publications and is calculated using the formula reported in [80]:

$$
\text { Doubling Time }(\mathrm{DT})=\frac{\ln 2}{\mathrm{RGR}}
$$

Table 1 shows the sequential increase in the research output by cumulative number, relative growth rate (RGR), and doubling time (DT). 
Table 1. Relative Growth Rate and Doubling Time.

\begin{tabular}{|c|c|c|c|c|c|c|c|c|}
\hline \multirow[b]{2}{*}{ Year } & \multicolumn{4}{|c|}{ Scopus Articles } & \multicolumn{4}{|c|}{ WoS Articles } \\
\hline & Records & Cumulative & RGR & DT & Records & Cumulative & RGR & DT \\
\hline 2000 & 60 & 60 & - & - & 55 & 55 & - & - \\
\hline 2001 & 60 & 120 & 0.69315 & 1.00000 & 51 & 106 & 0.65611 & 1.05646 \\
\hline 2002 & 85 & 205 & 0.53552 & 1.29435 & 72 & 178 & 0.51834 & 1.33723 \\
\hline 2003 & 98 & 303 & 0.39072 & 1.77401 & 58 & 236 & 0.28205 & 2.45755 \\
\hline 2004 & 116 & 419 & 0.32414 & 2.13843 & 71 & 307 & 0.26302 & 2.63538 \\
\hline 2005 & 137 & 556 & 0.2829 & 2.45017 & 84 & 391 & 0.24186 & 2.86590 \\
\hline 2006 & 153 & 709 & 0.24309 & 2.85143 & 96 & 487 & 0.21956 & 3.15703 \\
\hline 2007 & 222 & 931 & 0.2724 & 2.54456 & 138 & 625 & 0.24949 & 2.77828 \\
\hline 2008 & 232 & 1163 & 0.2225 & 3.11528 & 145 & 770 & 0.20864 & 3.32223 \\
\hline 2009 & 237 & 1400 & 0.18547 & 3.73726 & 167 & 937 & 0.19629 & 3.53119 \\
\hline 2010 & 245 & 1645 & 0.16127 & 4.29810 & 143 & 1080 & 0.14203 & 4.88018 \\
\hline 2011 & 252 & 1897 & 0.14253 & 4.86305 & 149 & 1229 & 0.12924 & 5.36326 \\
\hline 2012 & 253 & 2150 & 0.12519 & 5.53658 & 159 & 1388 & 0.12166 & 5.69727 \\
\hline 2013 & 258 & 2408 & 0.11333 & 6.11626 & 190 & 1578 & 0.12829 & 5.40279 \\
\hline 2014 & 260 & 2668 & 0.10253 & 6.76026 & 189 & 1767 & 0.11312 & 6.12727 \\
\hline 2015 & 279 & 2947 & 0.09946 & 6.96920 & 247 & 2014 & 0.13084 & 5.29769 \\
\hline 2016 & 286 & 3233 & 0.09262 & 7.48355 & 171 & 2185 & 0.08149 & 8.50560 \\
\hline
\end{tabular}

It is evident from Table 1 that there is a significant increase in the overall research output. The RGR and DT values show a clear upward trend for Scopus and WoS, which demonstrates the significance of this topic. The WoS showed a segmental increase and decrease, as well. Collectively, both indicate the dominance of Scopus in this area over WoS, except for 2015.

\subsection{Major Contributor Countries}

Table 2 shows the top 15 contributing countries researching this field. Table 2 shows that out of 5418 articles, the People's Republic of China is ranked number one, with 1030 articles $(588,442)$, providing $19.01 \%$ of the contributions to this field. Indeed, China has a very large population, and its housing and infrastructure projects play an important role in shaping the country's overall economic canvas. China's socio-economic conditions over the last 17 years from 2000 to 2016 were quite different to some of the worlds developed economies. Hence, the research undertaken in developed nations cannot not be easily adopted to the Chinese construction sector. Further, China has a significantly higher population and building density and less reusable energy per square meter of floor area [82]. These unique factors create a unique need to research this area. Consequently, China has produced its own research to find the best solution to its specific problems, which is one of the reasons why we see such a significant contribution from Chinese researchers.

Next is the USA $(602,389)$, with a total of 991 articles, contributing $18.29 \%$ of the field's research. England is in the third position, contributing 388 articles (7.161\%). Canada is in fourth position with $5.44 \%$, Germany is in the fifth position with $3.82 \%$, and Australia is sixth, with $3.61 \%$ of the contributions. The remainder of the contributors are shown in Table 2. 
Table 2. Top 15 contributing countries.

\begin{tabular}{ccccc}
\hline Number & Country/Territory & Scopus Articles & WOS Articles & Total \\
\hline 1 & China & 588 & 442 & 1030 \\
\hline 2 & United States & 602 & 389 & 991 \\
\hline 3 & United Kingdom & 247 & 141 & 388 \\
\hline 4 & Canada & 189 & 106 & 295 \\
\hline 5 & Germany & 127 & 80 & 207 \\
\hline 6 & Australia & 103 & 93 & 196 \\
\hline 7 & Spain & 99 & 89 & 188 \\
\hline 8 & Italy & 103 & 76 & 179 \\
\hline 9 & Taiwan & 93 & 74 & 167 \\
\hline 10 & France & 91 & 61 & 145 \\
\hline 11 & South Korea & 81 & 62 & 142 \\
\hline 12 & Poland & 73 & 48 & 135 \\
\hline 13 & Brazil & 83 & 56 & 131 \\
\hline 14 & Greece & 70 & 53 & 126 \\
\hline 15 & Netherlands & 69 & & 122 \\
\hline
\end{tabular}

Notably, European countries make a prominent appearance in the top 15 major contributors in the field of decision support systems in construction. Europe shares some common problems with China, such as limited usable land [83]. From an environmental perspective, the use of natural building materials in residential construction is far better than the use of bricks and other processed materials. For example, a wood-based house is $7.5 \%$ better than a brick house [84]. This is a concern for European countries because demolition is very common, which leads to construction waste, which causes serious environmental problems in its disposal. Thus, different strategies and laws were devised to tackle this issue. These issues have driven research in the area of sustainable construction [85], including legislation, policy development, etc.

Figure 2 presents an international collaboration network using the international collaboration papers (ICPs). The graph shows seven clusters in different colors. It shows that China has the strongest ties with England and Australia, USA with Spain, Germany with Canada, and Canada with Taiwan.

Furthermore, China has the highest number of ICP instances involving several other countries, such as Iran, Singapore, North Ireland, and Scotland. Both of the largest contributors (i.e., researchers from China and the USA) also have close ties and collaborations in research, specifically in decision support systems. Stevan D. Glaser from the university of California USA and Hui Li Harbin from the University of Technology China and others have worked in collaboration to develop innovative sensor technology to assess and monitor the structural health of buildings [1]. Researchers from Australia and Hong Kong have worked to manage the web based information flow for large construction projects [86]. Researchers from Australia and USA have worked to develop information collection and delivery systems based on the contextualized model framework [87]. Other collaborations among countries are shown in Figure 2. 


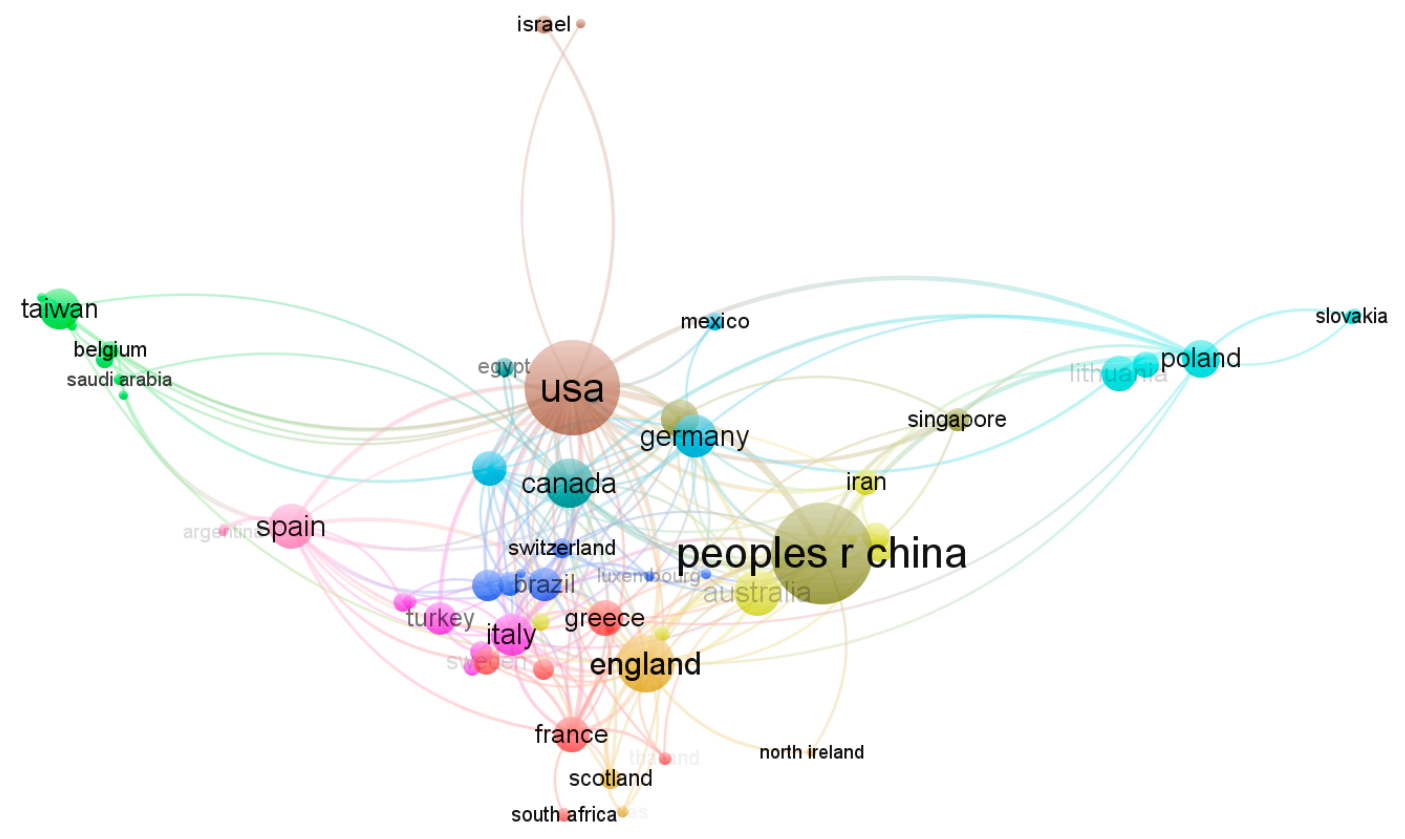

Figure 2. International Collaboration of Paper Network among Countries who have at least 2 published papers and 2 citations-WoS.

\subsection{Authorship and Collaboration Patterns}

To analyze the authorship and collaboration patterns, some important parameters were determined: Collaboration Index (CI), Degree of Collaboration (DC), and Collaborative Coefficient (CC). These were computed using the following formulas:

Collaboration Index (CI):

$$
\mathrm{CI}=\frac{\sum_{j=1}^{k} f j_{j}}{N}
$$

Degree of Collaboration (DC):

$$
\mathrm{DC}=1-\frac{f_{1}}{N}
$$

Collaborative Co-efficient (CC):

$$
\mathrm{CC}=1-\frac{\sum_{j=1}^{k} \frac{1}{j} f_{j}}{N}
$$

CI measures the mean number of authors per year and does not contain any upper limit. Thus, it cannot be interpreted as a degree [88]. It gives a non-zero weight for single-authored papers and for non-collaborative papers.

DC measures multi-authored papers, where " $f_{1}$ " is the number of papers written by a single author. Since DC has a value range between 0 and 1, it can be interpreted as a degree [89]. It gives a weight of 0 for single-author papers and 1 for multi-authored collaborative papers.

$\mathrm{CC}$ is used to quantify collaboration with a range of values between 0 and 1 (computed in Tables 3 and 4 [90]), where " $f j$ "is the number of research papers in a specific field of study having " $j$ " authors. " $N$ " is the number of the research papers, and " $k$ " is the maximum number of collaborating authors in that field of study [91]. Tables 3 and 4 show that most of the articles across both databases were written by multiple authors. Normally, articles featuring experimentation were written by two or more authors.

Most multi-authored papers are those that cover a large research topic or inter-disciplinary problems of research, such as light train transit systems [92], integrated water resource 
management [93,94], forests and timber harvesting [95], and different pollution patterns [96]. Some of those papers are written by authors from the same country [97] and some in collaboration with other countries [98]. The papers written by one or two authors handle much focused research problems, such as technical engineering issues [99], risk management, construction monitoring and decision support system (DSS) [100], e-procurement [101], infrastructure risk assessment [102], housing [103], and contractor selection [104].

Table 3. Authorship and Collaboration Patterns in WoS.

\begin{tabular}{clllllllllllll}
\hline & \multicolumn{10}{c}{ Number of Authors } \\
\hline No of Publications & Year & $\mathbf{1}$ & $\mathbf{2}$ & $\mathbf{3}$ & $\mathbf{4}$ & $\mathbf{5}$ & $\mathbf{6}$ & $\mathbf{7}$ & $\mathbf{8}$ & $\mathbf{C I}$ & $\mathbf{D C}$ & $\mathbf{C C}$ & $\mathbf{N}>\mathbf{3}$ \\
\hline $\mathbf{5 5}$ & 2000 & 10 & 16 & 11 & 10 & 5 & 1 & 1 & & 2.78182 & 0.81818 & 0.53680 & 17 \\
$\mathbf{5 1}$ & 2001 & 9 & 20 & 8 & 9 & 4 & & & 1 & 2.68627 & 0.82353 & 0.51291 & 14 \\
$\mathbf{7 2}$ & 2002 & 11 & 27 & 19 & 7 & 4 & 2 & 2 & & 2.72222 & 0.84722 & 0.52774 & 15 \\
$\mathbf{5 8}$ & 2003 & 5 & 20 & 16 & 7 & 3 & 3 & 1 & 1 & 2.91379 & 0.91379 & 0.59567 & 15 \\
$\mathbf{7 1}$ & 2004 & 8 & 14 & 29 & 11 & 6 & 1 & 1 & & 2.95775 & 0.88732 & 0.59259 & 19 \\
$\mathbf{8 4}$ & 2005 & 12 & 23 & 23 & 8 & 6 & 8 & 1 & 2 & 3.09524 & 0.85714 & 0.57032 & 25 \\
$\mathbf{9 6}$ & 2006 & 12 & 35 & 32 & 12 & 3 & 1 & 1 & & 2.64583 & 0.87500 & 0.54087 & 17 \\
$\mathbf{1 3 8}$ & 2007 & 12 & 47 & 33 & 27 & 7 & 10 & 2 & & 3.05797 & 0.91304 & 0.58984 & 46 \\
$\mathbf{1 4 5}$ & 2008 & 15 & 30 & 50 & 26 & 14 & 5 & 2 & 1 & 3.11034 & 0.89655 & 0.60544 & 48 \\
$\mathbf{1 6 7}$ & 2009 & 20 & 49 & 38 & 30 & 19 & 5 & 2 & & 2.94012 & 0.88024 & 0.58332 & 56 \\
$\mathbf{1 4 3}$ & 2010 & 23 & 35 & 46 & 22 & 8 & 3 & 3 & 1 & 2.83916 & 0.83916 & 0.55254 & 37 \\
$\mathbf{1 4 9}$ & 2011 & 28 & 47 & 36 & 20 & 8 & 7 & & 1 & 2.68456 & 0.81208 & 0.52086 & 36 \\
$\mathbf{1 5 9}$ & 2012 & 20 & 40 & 40 & 29 & 19 & 6 & & & 2.93711 & 0.87421 & 0.58878 & 54 \\
$\mathbf{1 9 0}$ & 2013 & 19 & 56 & 47 & 34 & 14 & 9 & 4 & 4 & 3.11579 & 0.90000 & 0.59717 & 65 \\
$\mathbf{1 8 9}$ & 2014 & 18 & 39 & 54 & 45 & 20 & 8 & 2 & 2 & 3.25926 & 0.90476 & 0.61577 & 77 \\
$\mathbf{2 4 7}$ & 2015 & 26 & 57 & 72 & 42 & 22 & 17 & 7 & 1 & 3.21053 & 0.89474 & 0.60584 & 89 \\
$\mathbf{1 7 1}$ & 2016 & 14 & 41 & 33 & 39 & 25 & 8 & 3 & 5 & 3.42105 & 0.91813 & 0.63370 & 80 \\
\hline
\end{tabular}

Table 4. Authorship and Collaboration Patterns in Scopus.

\begin{tabular}{clllllllllllll}
\hline & \multicolumn{10}{c}{ Number of Authors } \\
\hline No of Publications & Year & $\mathbf{1}$ & $\mathbf{2}$ & $\mathbf{3}$ & $\mathbf{4}$ & $\mathbf{5}$ & $\mathbf{6}$ & $\mathbf{7}$ & $\mathbf{8}$ & $\mathbf{C I}$ & $\mathbf{D C}$ & $\mathbf{C C}$ & $\mathbf{N}>\mathbf{3}$ \\
\hline $\mathbf{6 0}$ & 2000 & 5 & 9 & 12 & 7 & 3 & & & & 1.70000 & 0.91667 & 0.73583 & 10 \\
$\mathbf{6 0}$ & 2001 & 6 & 21 & 7 & 6 & 1 & 1 & & 1 & 1.86667 & 0.90000 & 0.65292 & 9 \\
$\mathbf{8 5}$ & 2002 & 9 & 21 & 11 & 8 & 7 & 3 & 1 & & 2.07059 & 0.89412 & 0.67989 & 19 \\
$\mathbf{9 8}$ & 2003 & 7 & 24 & 15 & 4 & 3 & 1 & 1 & & 1.46939 & 0.92857 & 0.73562 & 9 \\
$\mathbf{1 1 6}$ & 2004 & 15 & 19 & 23 & 11 & 2 & & & 2 & 1.65517 & 0.87069 & 0.69339 & 15 \\
$\mathbf{1 3 7}$ & 2005 & 8 & 26 & 29 & 6 & 8 & 4 & & 1 & 1.77372 & 0.94161 & 0.74775 & 19 \\
$\mathbf{1 5 3}$ & 2006 & 9 & 30 & 29 & 11 & 5 & 2 & & 1 & 1.60131 & 0.94118 & 0.75245 & 19 \\
$\mathbf{2 2 2}$ & 2007 & 8 & 53 & 26 & 21 & 12 & 4 & 1 & 1 & 1.68919 & 0.96396 & 0.76689 & 39 \\
$\mathbf{2 3 2}$ & 2008 & 15 & 30 & 51 & 22 & 11 & 4 & 2 & 2 & 1.83190 & 0.93534 & 0.75904 & 41 \\
$\mathbf{2 3 7}$ & 2009 & 23 & 52 & 38 & 30 & 8 & 5 & 1 & 1 & 1.88186 & 0.90295 & 0.69676 & 45 \\
$\mathbf{2 4 5}$ & 2010 & 15 & 23 & 38 & 23 & 10 & 1 & 2 & & 1.37551 & 0.93878 & 0.80666 & 36 \\
$\mathbf{2 5 2}$ & 2011 & 10 & 36 & 40 & 22 & 9 & 5 & 1 & 2 & 1.53968 & 0.96032 & 0.80214 & 39 \\
$\mathbf{2 5 3}$ & 2012 & 7 & 40 & 36 & 32 & 14 & 5 & & 2 & 1.73518 & 0.97233 & 0.79888 & 53 \\
$\mathbf{2 5 8}$ & 2013 & 12 & 34 & 45 & 35 & 10 & 4 & 2 & 1 & 1.74806 & 0.95349 & 0.78361 & 52 \\
$\mathbf{2 6 0}$ & 2014 & 9 & 26 & 29 & 33 & 17 & 3 & 2 & & 1.52692 & 0.96538 & 0.83038 & 55 \\
$\mathbf{2 7 9}$ & 2015 & 25 & 58 & 65 & 48 & 31 & 16 & 8 & 4 & 3.10753 & 0.91039 & 0.64811 & 107 \\
$\mathbf{2 8 6}$ & 2016 & 22 & 61 & 51 & 44 & 31 & 15 & 2 & 2 & 2.61538 & 0.92308 & 0.68624 & 94 \\
\hline
\end{tabular}

\subsection{Top 10 Contributing Authors}

Table 4 presents the top 10 contributing authors with their affiliated institutes. Notably, the top three authors are from Lithuania and Canada, which are of a lower rank in their overall articles published. "Zavadskas Ek" is first, with 42 articles, comprising $0.77 \%$ of the overall 5418 articles. Next are Abourizk, S. and Kaklauskas, A., who are both ranked second, with 32 articles, comprising $0.59 \%$ of all contributions. Cheng, M.Y. is ranked third, with 25 articles and $0.46 \%$ of the total contributions.

Figure 3 indicates the international collaboration of authors who have at least two published articles with a minimum of two citations. Here, there are 14 clusters represented by different colored bubbles. The collaboration graph shows clearly that Skibniewski, M.J. had many collaborations with Hong T., Zhang C., and Lee S., while Shen QP collaborated with Li H. 


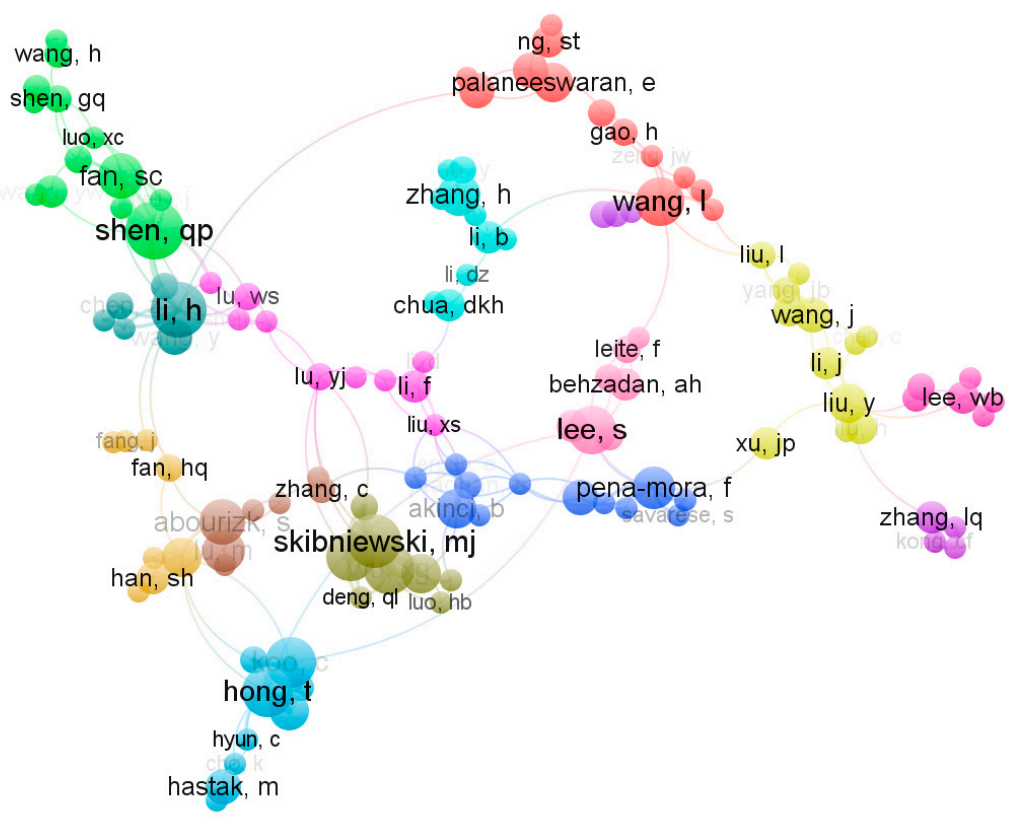

Figure 3. International Collaboration of paper network of authors who have at least 2 published papers and 2 citations-Web of Science (WoS).

\subsection{Top 10 Contributing Organizations}

Table 5 shows the top 10 organizations that contributed the most articles during the research period of 2000 to 2016 with relative percentages.

Table 5. Top 10 Authors with publications and affiliations.

\begin{tabular}{|c|c|c|c|c|c|c|c|}
\hline No & Authors & Key Research Areas & Affiliation & Scopus & WoS & $\begin{array}{c}\% \text { of } \\
\text { Scopus }\end{array}$ & $\%$ of WoS \\
\hline 1 & $\begin{array}{c}\text { Zavadskas } \\
\text { Ek }\end{array}$ & $\begin{array}{l}\text { MCDM, DSS, } \\
\text { Construction } \\
\text { Engineering and }\end{array}$ & $\begin{array}{l}\text { Vilnius Gediminas } \\
\text { Technical University, } \\
\text { Vilnius, Lithuania }\end{array}$ & 19 & 23 & 0.58769 & 1.05263 \\
\hline 2 & $\begin{array}{c}\text { Abourizk, } \\
\text { S. }\end{array}$ & $\begin{array}{c}\text { Construction } \\
\text { Operations, } \\
\text { Simulation Modelling, } \\
\text { Artificial Intelligence }\end{array}$ & $\begin{array}{l}\text { University of } \\
\text { Alberta, Hole } \\
\text { School of } \\
\text { Construction } \\
\text { Engineering and } \\
\text { Management, } \\
\text { Department of Civil } \\
\text { and Environmental } \\
\text { Engineering, } \\
\text { Canada }\end{array}$ & 24 & 8 & 0.74234 & 0.36613 \\
\hline 3 & $\begin{array}{c}\text { Kaklauska, } \\
\text { A. }\end{array}$ & $\begin{array}{l}\text { Informatics, } \\
\text { Construction } \\
\text { Management and } \\
\text { Economics, DSS }\end{array}$ & $\begin{array}{l}\text { Vilnius Gediminas } \\
\text { Tech Univ, Vilnius, } \\
\text { Lithuania }\end{array}$ & 11 & 21 & 0.34024 & 0.96110 \\
\hline 4 & Cheng, M.Y. & $\begin{array}{l}\text { Construction } \\
\text { management, } \\
\text { Artificial Intelligence, } \\
\text { Construction } \\
\text { Automation, GIS }\end{array}$ & $\begin{array}{l}\text { National Taiwan } \\
\text { University of } \\
\text { Science and } \\
\text { Technology, Dept of } \\
\text { Construction } \\
\text { Engineering, Taipei, } \\
\text { Taiwan }\end{array}$ & 13 & 12 & 0.40210 & 0.54920 \\
\hline
\end{tabular}


Table 5. Cont.

\begin{tabular}{|c|c|c|c|c|c|c|c|}
\hline No & Authors & Key Research Areas & Affiliation & Scopus & WoS & $\begin{array}{c}\% \text { of } \\
\text { Scopus }\end{array}$ & $\%$ of WoS \\
\hline 5 & $\begin{array}{c}\text { Skibniewski, } \\
\text { M.J. }\end{array}$ & $\begin{array}{c}\text { Construction } \\
\text { Automation, } \\
\text { Construction Tool } \\
\text { Management, Legal } \\
\text { Aspects in } \\
\text { Construction and } \\
\text { Project Management }\end{array}$ & $\begin{array}{l}\text { Department of Civil } \\
\text { and Environmental } \\
\text { Engineering, } \\
\text { University of } \\
\text { Maryland, College } \\
\text { Park, USA }\end{array}$ & 13 & 11 & 0.40210 & 0.50343 \\
\hline 6 & Zhang, L. & $\begin{array}{c}\text { 3D printing, } \\
\text { Prototyping, Natural } \\
\text { Science }\end{array}$ & $\begin{array}{c}\text { Huazhong } \\
\text { University Science } \\
\text { and Technology, } \\
\text { School of Civil } \\
\text { Engineering and } \\
\text { Mechanics, Wuhan, } \\
\text { Hubei, China }\end{array}$ & 12 & 9 & 0.37117 & 0.41190 \\
\hline 7 & Shen, $Q$. & $\begin{array}{c}\text { Construction } \\
\text { Management, Value } \\
\text { management, ICT, } \\
\text { DSS, Interactive Value } \\
\text { Management }\end{array}$ & $\begin{array}{l}\text { Hong Kong } \\
\text { Polytech University, } \\
\text { Department of } \\
\text { Buildings and Real } \\
\text { Estate, Kowloon, } \\
\text { Hong Kong, China }\end{array}$ & 8 & 13 & 0.24745 & 0.59497 \\
\hline 8 & Wu, X. & $\begin{array}{l}\text { Project Management, } \\
\text { Safety Management, } \\
\text { Sustainable } \\
\text { Development }\end{array}$ & $\begin{array}{l}\text { Huazhong Univ } \\
\text { Science and } \\
\text { Technology, School } \\
\text { Civil Engineering } \\
\text { and Mechanics, } \\
\text { Wuhan, Hubei, } \\
\text { China }\end{array}$ & 9 & 10 & 0.27838 & 0.45767 \\
\hline 9 & $\begin{array}{l}\text { Papageorgiou, } \\
\text { E.I. }\end{array}$ & $\begin{array}{c}\text { Intelligent Systems, } \\
\text { DSS, Data Mining } \\
\text { Techniques, } \\
\text { Intelligent Algorithms }\end{array}$ & $\begin{array}{c}\text { Technology } \\
\text { Educational } \\
\text { Institute of Lamia, } \\
\text { Department } \\
\text { Information and } \\
\text { Computer } \\
\text { Technology, Lamia, } \\
\text { Greece }\end{array}$ & 9 & 9 & 0.27838 & 0.41190 \\
\hline 10 & Fan, $\mathrm{H}$. & $\begin{array}{c}\text { Mechanics of } \\
\text { Materials, Disaster } \\
\text { Management, } \\
\text { Multiscale Modelling }\end{array}$ & $\begin{array}{l}\text { Yonsei University, } \\
\text { Department of Civil } \\
\text { and Environmental } \\
\text { Engineering, Seoul, } \\
\text { South Korea }\end{array}$ & 7 & 8 & 0.21652 & 0.36613 \\
\hline
\end{tabular}

Table 6 shows that Hong Kong universities are present in the top 10 table, while Hong Kong is not among the top 15 contributing countries.

In Scopus, Hong Kong Polytechnic University $(45,1.39 \%)$ shared first position with University of Alberta, Canada (45, 1.39\%). The University of Hong Kong $(26,0.80 \%)$ is ranked sixth, and the City University of Hong Kong $(22,0.68 \%)$ is ranked ninth.

In WoS, Vilnius Gediminas Technical University, Lithuania (51,2.33\%), is at the top, followed by Hong Kong Polytechnic University $(39,1.78 \%$ ) which is ranked second, City University of Hong Kong $(24,1.10 \%)$ (Ranked fourth), and University of Hong Kong (21, 0.96\%) (Ranked sixth).

China and USA are both present in the top 10 positions in the Scopus and WoS databases. The rest of the institutes are from Taiwan and Singapore.

Chinese universities have prominent rankings across both databases, with Huazhong University of Science and Technology, China (30,0.93\%), ranked third and Tsinghua University, China (24, $0.74 \%)$, ranked seventh in the Scopus database. In the WoS database, Huazhong University of Science Technology, China (23,1.05\%), is ranked fifth, and the Chinese Academy of Sciences, China (21, 0.96\%), is ranked eighth. 
Purdue University, USA (29, 0.90\%), is ranked fourth, and University of Maryland, USA (23, $0.71 \%)$, is ranked eighth in Scopus. Florida State University, USA (21, 0.96\%), is ranked seventh, and University System of Maryland, USA (19, 0.87\%), is ranked 10th.

Table 6. Top 10 Contributing Organizations.

\begin{tabular}{|c|c|c|c|c|c|c|}
\hline No. & Scopus & Articles & $\%$ of 3233 & Web of Science & Articles & $\%$ of 2185 \\
\hline 1 & $\begin{array}{l}\text { Hong Kong Polytechnic } \\
\text { University }\end{array}$ & 45 & 1.39 & $\begin{array}{l}\text { Vilnius Gediminas Technical } \\
\text { University }\end{array}$ & 51 & 2.33 \\
\hline 2 & University of Alberta & 45 & 1.39 & $\begin{array}{l}\text { Hong Kong Polytechnic } \\
\text { University }\end{array}$ & 39 & 1.78 \\
\hline 3 & $\begin{array}{l}\text { Huazhong University of } \\
\text { Science and Technology }\end{array}$ & 30 & 0.93 & $\begin{array}{l}\text { National Taiwan University Of } \\
\text { Science Technology }\end{array}$ & 28 & 1.28 \\
\hline 4 & Purdue University & 29 & 0.90 & City University Of Hong Kong & 24 & 1.10 \\
\hline 5 & $\begin{array}{l}\text { National Taiwan University of } \\
\text { Science and Technology }\end{array}$ & 29 & 0.90 & $\begin{array}{l}\text { Huazhong University Of } \\
\text { Science Technology }\end{array}$ & 23 & 1.05 \\
\hline 6 & The University of Hong Kong & 26 & 0.80 & University Of Hong Kong & 21 & 0.96 \\
\hline 7 & Tsinghua University & 24 & 0.74 & Florida State University System & 21 & 0.96 \\
\hline 8 & University of Maryland & 23 & 0.71 & Chinese Academy Of Sciences & 21 & 0.96 \\
\hline 9 & City University of Hong Kong & 22 & 0.68 & Yonsei University & 19 & 0.87 \\
\hline 10 & $\begin{array}{l}\text { National University of } \\
\text { Singapore }\end{array}$ & 22 & 0.68 & $\begin{array}{l}\text { University System Of } \\
\text { Maryland }\end{array}$ & 19 & 0.87 \\
\hline
\end{tabular}

3.10. Citation Details of Articles

Figure 4 shows that Scopus has 21,605 citations, whereas WoS has 15,950 citations.

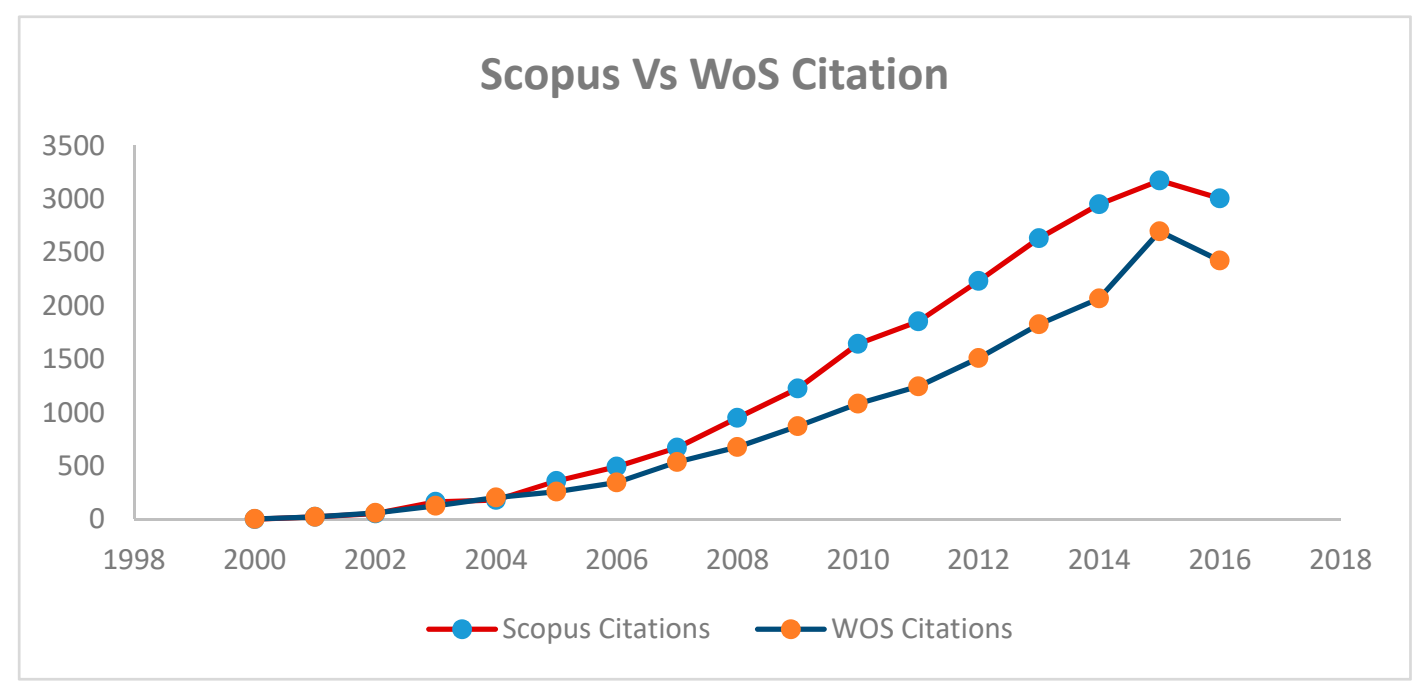

Figure 4. Total Citations per year during the period 2000-2016.

Figure 5 shows that Scopus has 5.216 citations and that WoS has 5.75 average citations per year per article. 


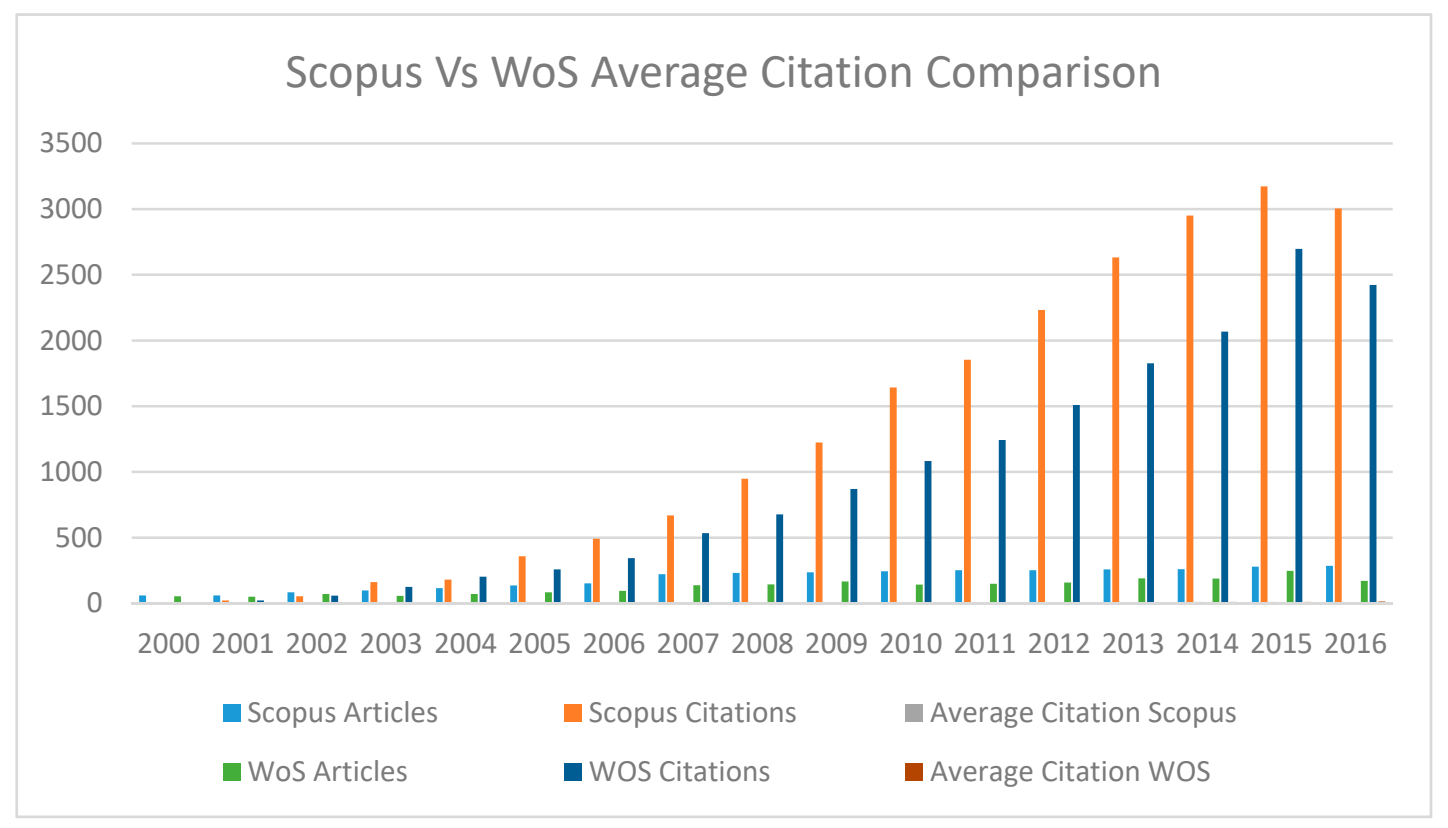

Figure 5. Average Citations per year per paper during the period 2000-2016.

\subsection{Top 25 Most Commonly Occurring Keywords}

Table 7 shows the top 25 most commonly occurring keywords from Scopus and WoS. We have arranged these key words in descending order. We identified the high frequency significant terms (i.e., control terms). It is quite clear from Table 6 that "Decision Support System", Decision Support Systems", and "Decision Support" are the most commonly occurring keywords, followed by "Data Mining", "Decision Making", and "Simulation". We used the VOS viewer to develop a keyword density visualization of the most common key words. Figures 6 and 7 show the Scopus and WoS keywords with at least five occurrences. It also shows the significant research keywords that appeared in both databases.

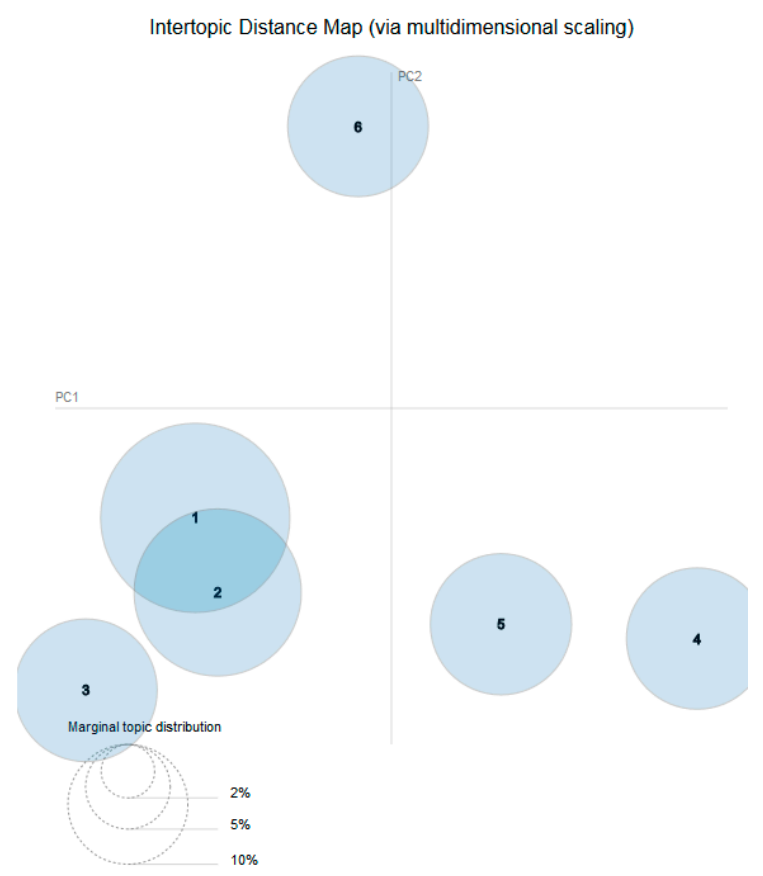

Figure 6. Intertopic Distance Map. 
Table 7. Top 25 Author Keywords from Scopus and WoS.

\begin{tabular}{ccccc}
\hline No. & Keywords & Scopus & Keywords & WoS \\
\hline 1 & Decision support system & 116 & Decision support system & 141 \\
2 & Decision Support & 96 & Decision support systems & 120 \\
3 & Decision support systems & 88 & Decision Support & 80 \\
4 & Data mining & 47 & Decision making & 53 \\
5 & Decision making & 44 & Construction & 48 \\
6 & Simulation & 44 & Simulation & 47 \\
7 & Construction management & 38 & GIS & 41 \\
8 & GIS & 35 & Construction management & 36 \\
9 & Construction management & 34 & Ontology & 35 \\
10 & Ontology & 29 & Fuzzy logic & 33 \\
11 & Project management & 26 & Sustainability & 32 \\
12 & Construction Industry & 26 & Knowledge management & 31 \\
13 & Fuzzy logic & 25 & Project management & 30 \\
14 & Optimization & 24 & Decision-making & 30 \\
15 & Artificial Intelligence & 23 & Artificial Intelligence & 29 \\
16 & Sustainability & 23 & Optimization & 24 \\
17 & Expert system & 20 & Construction industry & 23 \\
18 & Classification & 20 & Expert System & 20 \\
19 & Uncertainty & 18 & DSS & 19 \\
20 & Automation & 15 & Data warehouse & 18 \\
21 & Data warehouse & 15 & System dynamics & 18 \\
22 & BIM & 14 & Database & 14 \\
23 & Information management & 13 & Model & 13 \\
24 & Planning & 13 & Planning & 11 \\
25 & Risk & 11 & Risk & 11 \\
\hline
\end{tabular}

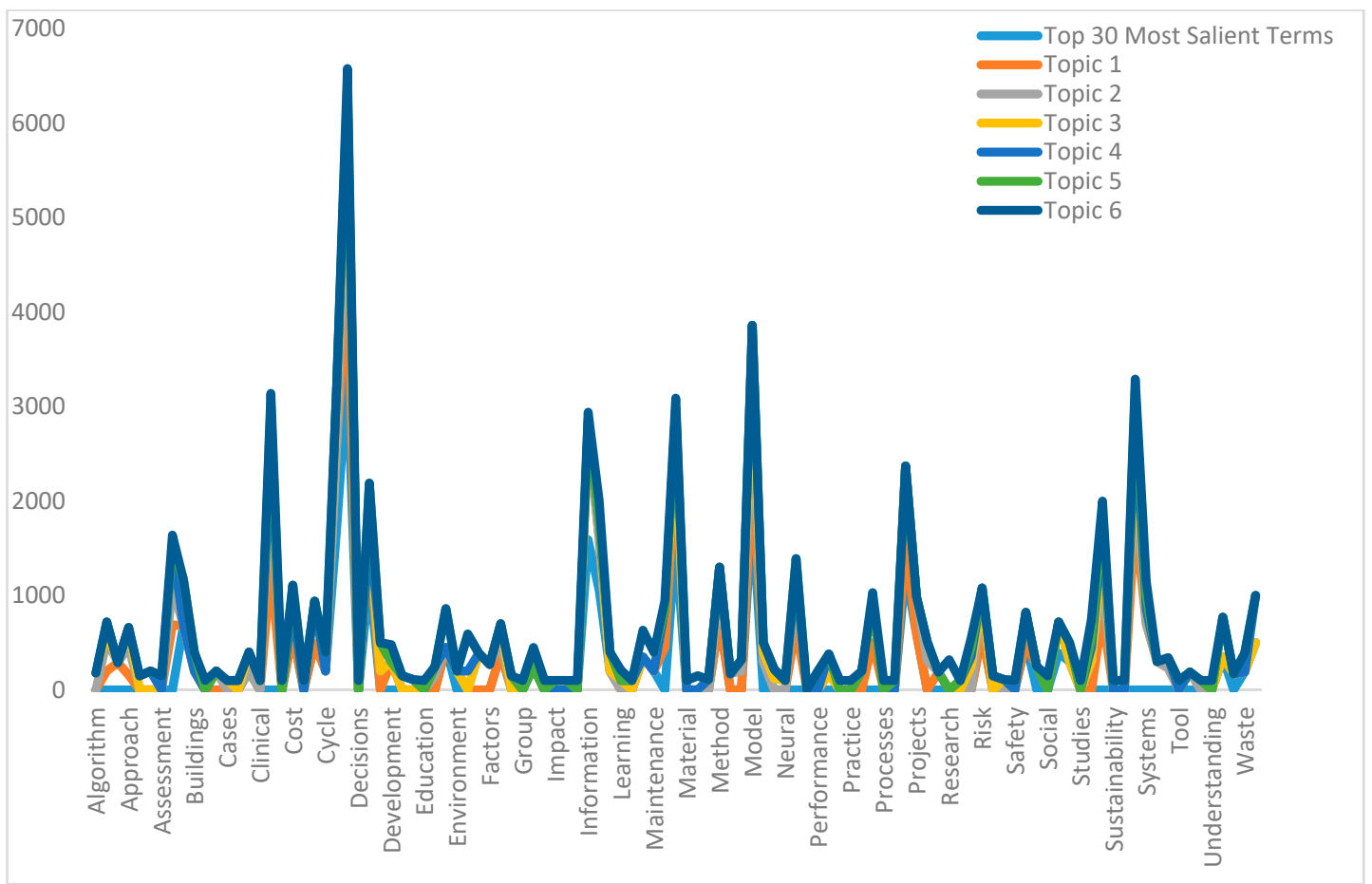

Figure 7. Topic Distrbution Map.

\subsection{Inter Topic Distance Map (Latent Dirichlet Allocation, LDA)}

We used the Latent Dirichlet Allocation (LDA) technique based on the idea that the probability of words can be expressed as a mixture of topics, where each topic is a probability distribution of the words. We utilized one of the popular models of LDA proposed by Blei et al. in 2003 [105]. In LDA, information collection is carried out in three major steps. For the given papers, distribution of 
the topic is sampled from Dirichlet distribution. For each word, a single topic is selected according to this distribution, and each word is sampled from a multinomial distribution of words specific to the sampled topic [106]. Figure 6 provides an inter-topic distance map via multidimensional scaling. It presents a graph with six circles showing different topic selections. We elaborated each topic and found the frequency distribution of each word that appears in each selected topic.

Figure 7 presents the top words appearing in each topic selection and the top 30 most salient terms. The words clinical, cycle, decision, information, maintenance, model, projects, sustainability, and systems appeared in almost every topic distribution, with a strong number of appearances during each topic selection.

\section{A New and Promising Area of Research}

The bibliometric analysis conducted in this article provided us with a true archetypal illustration of the research and technology shifts in the field of construction informatics and helped us to understand the overall revolutionary impact that information systems (IS) and information technology (IT) have made in the field over the last two decades. The results also indicate ongoing growth in research output in this area since 2007. However, numerous independent studies were found to lack proper cohesion, which is mostly attributed to the fact that the researchers followed their own personal research trajectories in isolation from other researchers. This has led to isolated objects of knowledge in specific areas within this field of research. The majority of this research is dominated by China, followed by the USA. Some European countries are also actively engaged in this area of research, especially researchers from Lithuania, who are collectively far ahead at the individual level compared to China or the USA.

Within the decision support systems area, some key research directions focused on risk assessment related to construction costs [107], energy management [108,109], construction equipment selection [110], construction method comparisons between piled embankment and traditional sand construction methods [111], resource reuse development for sustainable construction [112], consultant selection [113], timber harvesting systems [95], construction value management systems [114], cost optimization for complex railway portal construction [115], very tall building development [116], international contractor ratings [117], and emergency service centre locations [118].

Other actively researched areas include the selection of sustainable construction materials (Han, Kim, Chin, and Shin, 2009, [119]), air quality management (Zhivov, Herron, Durston, Heron, and Lea, 2014), and construction waste reduction [120].

The following key research clusters were identified by the bibliometric literature analysis in this field:

DSS for Construction Innovation: Research in this area investigated core issues such as the use of robots in construction, artificial intelligence, reconstruction materials, waste management, and cost control. The use of robots in construction that can work in real-time demonstrates the application of artificial intelligence in the construction sector [121]. The interaction of construction with the environment can be monitored using artificial intelligence by quantifying and spatially mapping the benefits provided by these systems [122]. Construction site selection [123] and demolition waste management (Marzouk and Azab, 2014) are field related factors. Several selection criteria, such as reconstruction materials [124], capital costs [125], corporate social responsibility [126], cost control [127], and construction visualization [128], were also identified by using the latest MCDM techniques, such as Electre III, which is used for optimal location selection for construction waste management [120]. The development of the innovation assessment index (IAI) and literature on IAI using rough set theory can be found in [129]. However, other methods (e.g., fuzzy approaches, data mining, etc. [130,131]) need further investigations. Similarly, low carbon technologies have been introduced on a massive scale to gauge global environmental change and sustainability and to boost the low carbon economy [132].

DSS for Design Issues: The research in this area focuses on the use of DSS to meet the design challenges in the construction sector, which is continuously being investigated [133]. The use of 
DSS for the purpose of designing mitigation strategies for construction safety risks was investigated by Qian and Lin, 2016. This system can increase employee safety at the start of the project (Titas, 2013). Most architects and engineers are concerned about risks and safety on site; hence, designing a risk analysis and mitigation approach is gaining attention in the literature [134]. Traditional building companies still follow old design processes, which limit the use of innovative energy efficient technologies. However, legislative changes are playing a critical role by introducing building codes that require energy efficient designs [135], simulation modelling with an e-commerce perspective [136], design flow [137], and decision support systems [137]. In the context of rain water tank design, design optimization can be achieved by using a simple decision support tool, such as a spread sheet containing rainfall data, the contributing roof area, the rainfall loss factor, the available storage factor, and tank overflow and irrigation water demand [138]. Algorithms designed with computational approaches have also been investigated to calculate the moments produced in steel frame structures to assess their impact on a building's structure [139]. Parametric modelling tools are used to combine complex structural designs with construction knowledge to develop generative rules and feedback rule checking criteria for conceptual design [140].

DSS for Construction Management: The research in this area focuses on the use of DSS for construction project management. Some key research directions include risk management modelling, domain knowledge management, flood management, and life cycle assessment to better understand the complexity of construction risk and safety management. Further, experience-based decision support and evolution model management system were developed [141]. Moreover, using domain ontology as a consistent platform for sharing project information, an artificial intelligent model was developed to relate the construction aspects of infrastructure products [142]. Conceptual multi model-based management information systems for simulation and decision making in construction projects were introduced to study both the management system owner and contractor firms and showed a paradigm shift (Kog and Yaman, 2014). Two dimensional GIS-based flood management decision support systems were shown to work practically within the framework of ArcGIS. This system can interact with remote sensing (RS) image layers and GIS feature layers [143]. Loosely integrated facilities and maintenance management systems were introduced; these systems work as a DSS by combining the transformation of the data, information, and knowledge captured and accumulated during the entire life cycle of a construction project [144].

Dynamic planning: This term is used for the combination of construction and project planning. The latest trends are discussed here for virtual construction site planning, irrigation planning, aggregate selection, 4D modelling, waste water infrastructure location planning, visualization tools, transport planning, and resource planning. Virtual construction site planning (VIRCON) [145], a decision support system (DSS), was developed to improve the planning and management of large irrigation schemes to analyze and evaluate the crops and crop scheme patterns cultivated to determine the limitations affecting crop selection based on yield [146]. The construction and maintenance of the infrastructure are based upon the selection of aggregate raw material. Lack of planning at the start can cause inconsistencies in the product cost [147], environmental performance [148], and confrontational relationship between the aggregate industry and community [149]. With the passage of time, the output from computer aided programs in the construction industry has become more demanding in order optimize resource utilization. The $4 \mathrm{D}$ model and $4 \mathrm{D}$ site management model were described to have a useful interphase with the 3D scheduled data from the computer graphics building model [150]. A combination of the planning and foundations of decision making techniques was discussed by Oleg, who noted a discrepancy between the evaluation of the attractiveness of techniques and methods from the perspectives of academics and managers of building companies [151]. Construction planning is driven by many factors, such as the definition of the work's tasks, estimation of the required resources, and the options of construction technology.

Geographic Information system (GIS)'s evolution has provided a new direction for the selection of waste water system locations in the terrains of specific areas. Different parameters were considered 
to minimize the construction and operational cost of such projects considering the topographic conditions of the area [152]. The construction industry uses planned areas because this industry requires many trades working simultaneously at the construction site. The GIS system is considered a good tool to assess construction safety planning [153]. To minimize the conflict between execution space interference in work-based activities, a critical space time (CSA) approach was developed by researchers using the computerized tool dubbed PECASO (Patterns execution and critical analysis of site space organization), which is a $4 \mathrm{D}$ space visualization and site planning tool [154]. Interchange is the most frequent and adaptable solution used to manage many intersections in the traffic planning process. The location issue is dealt with by merging different techniques and knowledge, such as bridge engineering, urban design, transport planning, technical specifications, and local and international standards, considering the structure, shape, landscape, and available site location (Rui, Qing-ning, Zhao-fei, and Zhao-hui, 2009). Construction companies are well-versed in using integrated planning and management software, such as ERP systems, to plan and manage mega projects in a precise way to avoid any jostles during the execution phase [155].

Fusion of the Latest Multi criteria decision making (MCDM) Techniques: Different multi criteria decision making techniques have been used under this heading, which clearly shows the pace of the evolution process and usage in the current construction industry. Major combinations include AHP and fuzzy and quantitative decision models. The limited resource factors of the government caused the emergence of BOT (Built, Operate and Transfer) projects. By incorporating the fusion of AHP and Utility Theory, an MDCM model was developed to support the selection process of BOT projects [156]. The execution of construction projects in a metropolitan area is risky, so competitive and dynamic approaches must be used to evaluate such projects. Fuzzy multiple criteria and fuzzy multiple attribute decision making approaches were established to systematically asses relevant risk factors [157]. The most important factor in the construction industry involves making accurate decisions at particular times and in particular situations. Multi-criteria decision making methods played a vital role in assisting this problem, particularly from an economic perspective [158]. Temporary housing units are used during the disaster management process. These houses are normally provided as prefabricated units that have many economic, environmental, and social issues. Thus, a DSS was developed to find the best functional value. The value function concept is used to facilitate this selection process when there is no other option [159]. Value analysis and multi attribute utility theory are used to determine the sustainability of the materials used in the sewerage pipe manufacturing process. The subjectivity involved is minimized by comparing the quantification of the different materials used in this process [160]. The reduction of carbon gases is treated as a major problem, especially during the construction phases. Almost $76 \%$ to $86 \%$ of this portion is produced during road construction. A quantitative decision model was developed to support the application of green technologies during road construction [161]. A decision model was developed by using quantitative measurement as an effective tool for big data analysis along with an algorithm to implement the latest modernization techniques in the building construction process [162]. A fuzzy expert system was used to develop a framework to identify and evaluate the causes of conflicts within a matrix organization in the construction industry. This system will help develop a suitable organizational structure that meets the requirements of the construction industry [163].

\section{Conclusions}

The basic aim of this paper was to provide concise information on the research topic of "Decision support systems in construction" to give future researchers and students to more detailed insight and more precise information using a bibliometric analysis, thereby synthesizing available information about the authors and countries with the largest numbers of contributions when searching for detailed work on this topic. This study endeavored to inspect the ongoing vagaries in the topic of decision support systems in construction. The factors discussed reflect the maturing stages and emerging trends in the field. There is no doubt that these stages are very common in the described years (2000 to 2016) 
of study. The gradual increase in the number of published articles shows an increase in the interest to work on decision support systems in the construction sector.

We found that China and the USA are the major players in this field of study, while Lithuania is the country with the top ranked authors. This trend shows the strength and growing trend towards DDS in the European region. Overall, the results are satisfactory for this research area, which continuously progressed over the studied period of time. In this paper, we successfully conducted analytic mapping of the research topic during the period of 2000 to 2016. The data obtained from Scopus and WoS, two major database sources, helped us analyze the different characteristics of our research topic. We used these two databases to obtain the raw data, and some combined research outputs and topics appeared during the data collection. We used these as single data-points to keep our data-set concise and non-repetitive. The basic motive to use bibliometric analysis was to study scholarly communication by tracing its history and evolution of ideas and quantifying the impacts of articles analytically. We provided details for the research output by year, country of output, countryand author-wise international collaboration patterns, authorship, important keywords, and a frequency visualization of those keywords.

All these analytical outcomes include computation of the latest bibliometric characteristics, including RGR, DT, CI, DC, and CC. We found and presented information about the top contributors in the form of countries and authors along with their affiliate institutes and their collaboration patterns both countrywide and internationally. The top authors and their fields of interest and research by year. The major future research directions include simulation modelling, artificial intelligence, construction automation, 3D prototyping, remote sensing and controlling, interactive value management, sustainable development, and management. We identified important control terms, comprehensive analyses, and the latest bibliometric characterizations in this research field.

Author Contributions: M.R.M. gathered all the data, run the analysis, presented in graphical way and compile in presented format. V.P. cross checked all the information and validated the results with his experience in IS. All authors have read and agreed to the published version of the manuscript.

Funding: This research received no external funding.

Conflicts of Interest: The authors declare no conflict of interest.

\section{References}

1. Chandwani, V.; Agrawal, V.; Nagar, R. Modeling slump of ready mix concrete using genetic algorithms assisted training of Artificial Neural Networks. Expert Syst. Appl. 2015, 42, 885-893. [CrossRef]

2. Monghasemi, S.; Nikoo, M.R.; Khaksar Fasaee, M.A.; Adamowski, J. A novel multi criteria decision making model for optimizing time-cost-quality trade-off problems in construction projects. Expert Syst. Appl. 2015, 42, 3089-3104. [CrossRef]

3. Grošelj, P.; Zadnik Stirn, L.; Ayrilmis, N.; Kuzman, M.K. Comparison of some aggregation techniques using group analytic hierarchy process. Expert Syst. Appl. 2015, 42, 2198-2204. [CrossRef]

4. Rosenman, M.; Wang, F. A component agent based open CAD system for collaborative design. Autom. Constr. 2001, 10, 383-397. [CrossRef]

5. Elmualim, A.; Gilder, J. BIM: Innovation in design management, influence and challenges of implementation. Archit. Eng. Des. Manag. 2014, 10, 183-199. [CrossRef]

6. Volk, R.; Stengel, J.; Schultmann, F. Building Information Modeling (BIM) for existing buildings-Literature review and future needs. Autom. Constr. 2014, 38, 109-127. [CrossRef]

7. Moon, K.S. Optimal Grid Geometry of Diagrid Structures for Tall Buildings. Archit. Sci. Rev. 2008, 51, 239-251. [CrossRef]

8. Thompson, B.P.; Bank, L.C. Use of system dynamics as a decision-making tool in building design and operation. Build. Environ. 2010, 45, 1006-1015. [CrossRef]

9. Bank, L.C.; Thompson, B.P.; McCarthy, M. Decision-making tools for evaluating the impact of materials selection on the carbon footprint of buildings. Carbon Manag. 2011, 2, 431-441. [CrossRef] 
10. Lee, S.H.; Peña-Mora, F.; Park, M. Dynamic planning and control methodology for strategic and operational construction project management. Autom. Constr. 2006, 15, 84-97. [CrossRef]

11. Williams, P. Builders' Quantities. In Managing Measurement Risk in Building and Civil Engineering; John Wiley \& Sons, Ltd.: Chichester, UK, 2015; pp. 565-571.

12. Corgnati, S.P.; Fabrizio, E.; Filippi, M.; Monetti, V. Reference buildings for cost optimal analysis: Method of definition and application. Appl. Energy 2013, 102, 983-993. [CrossRef]

13. Kneifel, J. Life-cycle carbon and cost analysis of energy efficiency measures in new commercial buildings. Energy Build. 2010, 42, 333-340. [CrossRef]

14. Asadi, E.; da Silva, M.G.; Antunes, C.H.; Dias, L. Multi-objective optimization for building retrofit strategies: A model and an application. Energy Build. 2012, 44, 81-87. [CrossRef]

15. Fadaee, M.; Radzi, M.A.M. Multi-objective optimization of a stand-alone hybrid renewable energy system by using evolutionary algorithms: A review. Renew. Sustain. Energy Rev. 2012, 16, 3364-3369. [CrossRef]

16. Juan, Y.K.; Gao, P.; Wang, J. A hybrid decision support system for sustainable office building renovation and energy performance improvement. Energy Build. 2010, 42, 290-297. [CrossRef]

17. Jaffal, I.; Ouldboukhitine, S.-E.; Belarbi, R. A comprehensive study of the impact of green roofs on building energy performance. Renew. Energy 2012, 43, 157-164. [CrossRef]

18. Hwang, B.-G.; Ng, W.J. Project management knowledge and skills for green construction: Overcoming challenges. Int. J. Proj. Manag. 2013, 31, 272-284. [CrossRef]

19. Deuble, M.P.; de Dear, R.J. Green occupants for green buildings: The missing link? Build. Environ. 2012, 56, 21-27. [CrossRef]

20. Jung, Y.; Joo, M. Building information modelling (BIM) framework for practical implementation. Autom. Constr. 2011, 20, 126-133. [CrossRef]

21. Zhang, S.; Teizer, J.; Lee, J.-K.; Eastman, C.M.; Venugopal, M. Building Information Modeling (BIM) and Safety: Automatic Safety Checking of Construction Models and Schedules. Autom. Constr. 2013, 29, $183-195$. [CrossRef]

22. Popov, V.; Juocevicius, V.; Migilinskas, D.; Ustinovichius, L.; Mikalauskas, S. The use of a virtual building design and construction model for developing an effective project concept in 5D environment. Autom. Constr. 2010, 19, 357-367. [CrossRef]

23. Ascione, F.; Bianco, N.; De Stasio, C.; Mauro, G.M.; Vanoli, G.P. A new methodology for cost-optimal analysis by means of the multi-objective optimization of building energy performance. Energy Build. 2015, 88, 78-90. [CrossRef]

24. Ramesh, T.; Prakash, R.; Shukla, K.K. Life cycle energy analysis of buildings: An overview. Energy Build. 2010, 42, 1592-1600. [CrossRef]

25. Peng, J.; Lu, L.; Yang, H. Review on life cycle assessment of energy payback and greenhouse gas emission of solar photovoltaic systems. Renew. Sustain. Energy Rev. 2013, 19, 255-274. [CrossRef]

26. Heo, Y.; Choudhary, R.; Augenbroe, G.A. Calibration of building energy models for retrofit analysis under uncertainty. Energy Build. 2012, 47, 550-560. [CrossRef]

27. Castleton, H.F.; Stovin, V.; Beck, S.B.M.; Davison, J.B. Green roofs; building energy savings and the potential for retrofit. Energy Build. 2010, 42, 1582-1591. [CrossRef]

28. Ardente, F.; Beccali, M.; Cellura, M.; Mistretta, M. Energy and environmental benefits in public buildings as a result of retrofit actions. Renew. Sustain. Energy Rev. 2011, 15, 460-470. [CrossRef]

29. Baetens, R.; Jelle, B.P.; Gustavsen, A. Properties, requirements and possibilities of smart windows for dynamic daylight and solar energy control in buildings: A state-of-the-art review. Sol. Energy Mater. Sol. Cells 2010, 94, 87-105. [CrossRef]

30. Sadineni, S.B.; Madala, S.; Boehm, R.F. Passive building energy savings: A review of building envelope components. Renew. Sustain. Energy Rev. 2011, 15, 3617-3631. [CrossRef]

31. Abd Rashid, A.F.; Yusoff, S. A review of life cycle assessment method for building industry. Renew. Sustain. Energy Rev. 2015, 45, 244-248. [CrossRef]

32. Ochoa, C.E.; Capeluto, I.G. Decision methodology for the development of an expert system applied in an adaptable energy retrofit façade system for residential buildings. Renew. Energy 2015, 78, 498-508. [CrossRef]

33. Turskis, Z.; Zavadskas, E.K.; Peldschus, F. Multi-criteria Optimization System for Decision Making in Construction Design and Management. Eng. Econ. 2015, 61, 7-17. 
34. Durieux, V.; Gevenois, P.A. Bibliometric Indicators: Quality Measurements of Scientific Publication. Radiology 2010, 255, 342-351. [CrossRef]

35. Moed, H.F. New developments in the use of citation analysis in research evaluation. Arch. Immunol. Ther. Exp. 2009, 57, 13. [CrossRef]

36. Daim, T.U.; Rueda, G.; Martin, H.; Gerdsri, P. Forecasting emerging technologies: Use of bibliometrics and patent analysis. Technol. Forecast. Soc. Chang. 2006, 73, 981-1012. [CrossRef]

37. Jänicke, M. "Green growth": From a growing eco-industry to economic sustainability. Energy Policy 2012, 48, 13-21. [CrossRef]

38. Mehmet, A.; Boz, I.; El-adaway, H. Creating a Holistic Systems Framework for Sustainability Assessment of Civil Infrastructure Projects. J. Constr. Eng. Manag. 2015, 141, 04014067.

39. Kontoleon, K.J.; Eumorfopoulou, E.A. The effect of the orientation and proportion of a plant-covered wall layer on the thermal performance of a building zone. Build. Environ. 2010, 45, 1287-1303. [CrossRef]

40. Robichaud, L.B.; Anantatmula, V.S. Greening Project Management Practices for Sustainable Construction. J. Manag. Eng. 2011, 27, 48-57. [CrossRef]

41. Jato-Espino, D.; Castillo-Lopez, E.; Rodriguez-Hernandez, J.; Canteras-Jordana, J.C. A review of application of multi-criteria decision making methods in construction. Autom. Constr. 2014, 45, 151-162. [CrossRef]

42. Robert, A.; Kummert, M. Designing net-zero energy buildings for the future climate, not for the past. Build. Environ. 2012, 55, 150-158. [CrossRef]

43. Wei, C.; Li, Y. Design of energy consumption monitoring and energy-saving management system of intelligent building based on the Internet of things. In Proceedings of the 2011 International Conference on Electronics, Communications and Control (ICECC), Ningbo, China, 9-11 September 2011; pp. 3650-3652.

44. Sharma, A.; Saxena, A.; Sethi, M.; Shree, V. Life cycle assessment of buildings: A review. Renew. Sustain. Energy Rev. 2011, 15, 871-875. [CrossRef]

45. Gustavsson, L.; Joelsson, A. Life cycle primary energy analysis of residential buildings. Energy Build. 2010, 42, 210-220. [CrossRef]

46. Guan, X.; Xu, Z.; Jia, Q.S. Energy-Efficient Buildings Facilitated by Microgrid. IEEE Trans. Smart Grid 2010, 1, 243-252. [CrossRef]

47. Gulbinas, R.; Jain, R.K.; Taylor, J.E. BizWatts: A modular socio-technical energy management system for empowering commercial building occupants to conserve energy. Appl. Energy 2014, 136, 1076-1084. [CrossRef]

48. Syal, M.; Duah, D.; Samuel, S.; Mazor, M.; Mo, Y.; Cyr, T. Information Framework for Intelligent Decision Support System for Home Energy Retrofits. J. Constr. Eng. Manag. 2014, 140, 04013030. [CrossRef]

49. SM Energy. Energy-Efficient Retrofits \& Weatherization; ProQuest Dissertations Publishing; SM energy: Denver, CO, USA, 2011.

50. Fulton, M.; Baker, J.; Brandenburg, M.; Herbst, R.; Cleveland, J.; Rogers, J.; Onyeagoro, C. United States Building Energy Efficiency Retrofits: Market Sizing and Financing Models. Deutsche Bank Climate. 2012. Available online: https:/www.buildup.eu/en/news/united-states-building-energy-efficiency-retrofitsmarket-sizing-and-financing-models (accessed on 13 June 2014).

51. Gajzler, M. Text and data mining techniques in aspect of knowledge acquisition for decision support system in construction industry. Ukio Technol. Ir. Ekon. Vystym. 2010, 16, 219-232.

52. Hopfe, C.J.; Hensen, J.L.M. Uncertainty analysis in building performance simulation for design support. Energy Build. 2011, 43, 2798-2805. [CrossRef]

53. Hopfe, C.J.; Augenbroe, G.L.M.; Hensen, J.L.M. Multi-criteria decision making under uncertainty in building performance assessment. Build. Environ. 2013, 69, 81-90. [CrossRef]

54. Shen, W.; Hao, Q.; Mak, H.; Neelamkavil, J.; Xie, H.; Dickinson, J. Systems integration and collaboration in architecture, engineering, construction, and facilities management: A review. Adv. Eng. Inform. 2010, 24, 196-207. [CrossRef]

55. Kanapeckiene, L.; Kaklauskas, A.; Zavadskas, E.K.; Raslanas, S. Method and system for Multi-Attribute Market Value Assessment in analysis of construction and retrofit projects. Expert Syst. Appl. 2011, 38, 14196-14207. [CrossRef]

56. Cheng, M.Y.; Peng, H.S.; Wu, Y.W.; Chen, T.L. Estimate at Completion for construction projects using Evolutionary Support Vector Machine Inference Model. Autom. Constr. 2010, 19, 619-629. [CrossRef] 
57. Research in Modeling and Simulation for Improving Construction Engineering Operations. J. Constr. Eng. Manag. 2011, 137, 137,843-852.

58. Cinelli, M.; Coles, S.R.; Kirwan, K. Analysis of the potentials of multi criteria decision analysis methods to conduct sustainability assessment. Ecol. Indic. 2014, 46, 138-148. [CrossRef]

59. A Review of Sustainability Assessment and Sustainability/Environmental Rating Systems and Credit Weighting Tools-ProQuest. Available online: http://search.proquest.com/openview/ ea5364756ebd754793edac64e1e0ec83/1?pq-origsite=gscholar\&cbl=307060 (accessed on 6 December 2011).

60. Blank, L.; Vasl, A.; Levy, S.; Grant, G.; Kadas, G.; Dafni, A. Directions in green roof research: A bibliometric study. Build. Environ. 2013, 66, 23-28. [CrossRef]

61. Cañas, I.; Martín, S. Recovery of Spanish vernacular construction as a model of bioclimatic architecture. Build. Environ. 2004, 39, 1477-1495. [CrossRef]

62. Chen, Y.; Okudan, G.E.; Riley, D.R. Sustainable performance criteria for construction method selection in concrete buildings. Autom. Constr. 2010, 19, 235-244. [CrossRef]

63. Attia, S.; Gratia, E.; De Herde, A.; Hensen, J.L.M. Simulation-based decision support tool for early stages of zero-energy building design. Energy Build. 2012, 49, 2-15. [CrossRef]

64. Li, X.; Ouelhadj, D.; Song, X.; Jones, D.; Wall, G.; Howell, K.E. A decision support system for strategic maintenance planning in offshore wind farms. Renew. Energy 2016, 99, 784-799. [CrossRef]

65. Kabashkin, I. Heuristic Based Decision Support System for Choice of Alternative Routes in the Large-Scale Transportation Transit System on the Base of Petri Net Model. Procedia Eng. 2016, 134, 359-364. [CrossRef]

66. Cañas-Guerrero, I.; Mazarrón, F.R.; Calleja-Perucho, C.; Pou-Merina, A. Bibliometric analysis in the international context of the "Construction \& Building Technology" category from the Web of Science database. Constr. Build. Mater. 2014, 53, 13-25.

67. Yang, L.; Chen, Z.; Liu, T.; Gong, Z.; Yu, Y.; Wang, J. Global trends of solid waste research from 1997 to 2011 by using bibliometric analysis. Scientometrics 2013, 96, 133-146. [CrossRef]

68. Friege, J.; Chappin, E. Modelling decisions on energy-efficient renovations: A review. Renew. Sustain. Energy Rev. 2014, 39, 196-208. [CrossRef]

69. Abramo, G.; D'Angelo, C.A. Evaluating research: From informed peer review to bibliometrics. Scientometrics 2011, 87, 499-514. [CrossRef]

70. Costas, R.; van Leeuwen, T.N.; Bordons, M. A bibliometric classificatory approach for the study and assessment of research performance at the individual level: The effects of age on productivity and impact. J. Am. Soc. Inf. Sci. Technol. 2010, 61, 1564-1581. [CrossRef]

71. Hjørland, B. Citation analysis: A social and dynamic approach to knowledge organization. Inf. Process. Manag. 2013, 49, 1313-1325. [CrossRef]

72. Hicks, D.; Melkers, J. Bibliometrics as a Tool for Research Evaluation. 2012. Available online: https://works.bepress.com/diana_hicks/31/ (accessed on 28 February 2013).

73. Bornmann, L.; Leydesdorff, L.; Mutz, R. The use of percentiles and percentile rank classes in the analysis of bibliometric data: Opportunities and limits. J. Informetr. 2013, 7, 158-165. [CrossRef]

74. Norris, M.; Oppenheim, C. The h-index: A broad review of a new bibliometric indicator. J. Doc. 2010, 66, 681-705. [CrossRef]

75. Mryglod, O.; Kenna, R.; Holovatch, Y.; Berche, B. Comparison of a citation-based indicator and peer review for absolute and specific measures of research-group excellence. Scientometrics 2013, 97, 767-777. [CrossRef]

76. Liu, X.; Zhang, J.; Guo, C. Full-text citation analysis: A new method to enhance scholarly networks. J. Am. Soc. Inf. Sci. Technol. 2013, 64, 1852-1863. [CrossRef]

77. Van Eck, N.J.; Waltman, L.; Dekker, R.; van den Berg, J. A comparison of two techniques for bibliometric mapping: Multidimensional scaling and VOS. J. Am. Soc. Inf. Sci. Technol. 2010, 61, 2405-2416. [CrossRef]

78. Cobo, M.J.; López-Herrera A g Herrera-Viedma, E.; Herrera, F. Science mapping software tools: Review, analysis, and cooperative study among tools. J. Am. Soc. Inf. Sci. Technol. 2011, 62, 1382-1402. [CrossRef]

79. Knutas, A.; Hajikhani, A.; Salminen, J.; Ikonen, J.; Porras, J. Cloud-based Bibliometric Analysis Service for Systematic Mapping Studies. In Proceedings of the 16th International Conference on Computer Systems and Technologies, New York, NY, USA, 25-26 June 2015; pp. 184-191.

80. Singh, V.K.; Banshal, S.K.; Singhal, K.; Uddin, A. Scientometric mapping of research on 'Big Data' . Scientometrics 2015, 105, 727-741. [CrossRef] 
81. Mahapatra, M. On the validity of the theory of exponential growth of scientific literature. In Proceedings of the 15th IASLIC Conference, Bangalore, India, 26-29 July 1985; pp. 61-70.

82. Zhu, Y.; Lin, B. Sustainable housing and urban construction in China. Energy Build. 2004, 36, 1287-1297. [CrossRef]

83. Wang, J.; Chen, Y.; Shao, X.; Zhang, Y.; Cao, Y. Land-use changes and policy dimension driving forces in China: Present, trend and future. Land Use Policy 2012, 29, 737-749. [CrossRef]

84. Medineckiene, M.; Turskis, Z.; Zavadskas, E.K. Sustainable construction taking into account the building impact on the environment. J. Environ. Eng. Landsc. Manag. 2010, 18, 118-127. [CrossRef]

85. Del Río Merino, M.; Izquierdo Gracia, P.; Weis Azevedo, I.S. Sustainable construction: Construction and demolition waste reconsidered. Waste Manag. Res. 2010, 28, 118-129. [CrossRef]

86. Li, H.; Tang, S.; Love, P.E.D. VHBuild.com: A Web-based system for managing knowledge in projects. Internet Res. 2002, 12, 371-379. [CrossRef]

87. Paris, C.; Wu, M.; Linden, K.V.; Post, M.; Lu, S. Myriad: An Architecture for Contextualized Information Retrieval and Delivery. In Adaptive Hypermedia and Adaptive Web-Based Systems; Springer: Berlin/Heidelberg, Germany, 2004; pp. 205-214.

88. Liao, C.H.; Yen, H.R. Quantifying the degree of research collaboration: A comparative study of collaborative measures. J. Informetr. 2012, 6, 27-33. [CrossRef]

89. Subramanyam, K. Bibliometric studies of research collaboration: A review. Inf. Sci. 1983, 6, 33-38. [CrossRef]

90. Derudder, B.; Timberlake, M.; Witlox, F.; Matthiessen, C.W.; Schwarz, A.W.; Find, S. World Cities of Scientific Knowledge: Systems, Networks and Potential Dynamics. An Analysis Based on Bibliometric Indicators. Urban Stud. 2010, 47, 1879-1897.

91. Gajzler, M. The Idea of Knowledge Supplementation and Explanation Using Neural Networks to Support Decisions in Construction Engineering. Procedia Eng. 2013, 57, 302-309. [CrossRef]

92. Kim, G.T.; Kim, K.T.; Lee, D.H.; Han, C.H.; Kim, H.B.; Jun, J.T. Development of a life cycle cost estimate system for structures of light rail transit infrastructure. Autom. Constr. 2010, 19, 308-325. [CrossRef]

93. Molina, J.L.; Bromley, J.; García-Aróstegui, J.L.; Sullivan, C.; Benavente, J. Integrated water resources management of overexploited hydrogeological systems using Object-Oriented Bayesian Networks. Environ. Model. Softw. 2010, 25, 383-397. [CrossRef]

94. Liu, J.; Gao, X.; Shao, W.; Han, J.; Gong, J.; Niu, C. Water Resources Monitoring System Construction in Shanxi Province, China. Procedia Eng. 2016, 154, 326-333. [CrossRef]

95. Kühmaier, M.; Stampfer, K. Development of a Multi-Attribute Spatial Decision Support System in Selecting Timber Harvesting Systems. Croat. J. For. Eng. J. Theory Appl. For. Eng. 2010, 31, 75-88.

96. Song, X.X.; Hou, D.B.; Huang, P.J.; Zhang, G.X. Research on Dynamic early Warning Technology of Water Pollution Emergency Based on Pollutant Dispersion Simulation. Appl. Mech. Mater. 2013, 316, 682-685. [CrossRef]

97. Kaiser, M.J.; Pulsipher, A.G. The impact of weather and ocean forecasting on hydrocarbon production and pollution management in the Gulf of Mexico. Energy Policy 2007, 35, 966-983. [CrossRef]

98. Palaneeswaran, E.; Love, P.E.D.; Kumaraswamy, M.M.; Ng, T.S.T. Mapping rework causes and effects using artificial neural networks. Build. Res. Inf. 2008, 36, 450-465. [CrossRef]

99. Zavadskas, E.K.; Trinkūnas, V.; Kaklauskas, A. Reasoned Decisions in Construction Materials Selection. 2008. Available online: http://dspace.vgtu.lt/handle/1/458 (accessed on 26 June 2008).

100. Hazır, Ö. A review of analytical models, approaches and decision support tools in project monitoring and control. Int. J. Proj. Manag. 2015, 33, 808-815. [CrossRef]

101. Idrees, A.M. Towards an automated evaluation approach for e-procurement. In Proceedings of the 201513 th International Conference on ICT and Knowledge Engineering (ICT Knowledge Engineering 2015), Bangkok, Thailand, 18-20 November 2015; pp. 67-71.

102. Ellingwood, B.R. Risk-informed condition assessment of civil infrastructure: State of practice and research issues. Struct. Infrastruct. Eng. 2005, 1, 7-18. [CrossRef]

103. Rebelo, E.M. How Social Housing Can Benefit from the Competitive Market. 2002. Available online: http://repositorio-aberto.up.pt/handle/10216/96554 (accessed on 20 April 2020).

104. Jaskowski, P.; Biruk, S.; Bucon, R. Assessing contractor selection criteria weights with fuzzy AHP method application in group decision environment. Autom. Constr. 2010, 19, 120-126. [CrossRef]

105. Blei, D.M.; Ng, A.Y.; Jordan, M.I. Latent Dirichlet Allocation. J. Mach. Learn. Res. 2003, 3, 993-1022. 
106. Hassan, S.U.; Haddawy, P. Analyzing knowledge flows of scientific literature through semantic links: A case study in the field of energy. Scientometrics 2015, 103, 33-46. [CrossRef]

107. Laryea, S. Risk apportionment in target cost contracts. Proc. Inst. Civ. Eng. Manag. Procure. Law 2016, 169, 248-257. [CrossRef]

108. Kovacic, I.; Waltenbereger, L.; Gourlis, G. Tool for life cycle analysis of facade-systems for industrial buildings. J. Clean. Prod. 2016, 130, 260-272. [CrossRef]

109. Nogueira de Oliveira, L.P.; Rodriguez Rochedo, P.R.; Portugal-Pereira, J.; Hoffmann, B.S.; Aragão, R.; Milani, R. Critical technologies for sustainable energy development in Brazil: Technological foresight based on scenario modelling. J. Clean. Prod. 2016, 130, 12-24. [CrossRef]

110. Marzouk, M.; Abubakr, A. Decision support for tower crane selection with building information models and genetic algorithms. Autom. Constr. 2016, 61, 1-15. [CrossRef]

111. Van Eekelen, S.J.M.; Venmans, A.A.M. Piled Embankment or a Traditional Sand Construction: How to Decide? A Case Study. Procedia Eng. 2016, 143, 590-597. [CrossRef]

112. Ali, A.K.; Badinelli, R. Novel Integration of Sustainable and Construction Decisions into the Design Bid Build Project Delivery Method Using BPMN. Procedia Eng. 2016, 145, 164-171. [CrossRef]

113. Omar, M.F.; Trigunarsyah, B.; Wong, J. A Design Science Approach for Consultant Selection Decision Support System. In Proceedings of the 2009 Fourth International Conference on Cooperation and Promotion of Information Resources in Science and Technology, Beijing, China, 21-23 November 2009; pp. 90-94.

114. Luo, X.; Shen, G.Q.; Fan, S.; Xue, X. A group decision support system for implementing value management methodology in construction briefing. Int. J. Proj. Manag. 2011, 29, 1003-1017. [CrossRef]

115. Saa, R.; Garcia, A.; Gomez, C.; Carretero, J.; Garcia-Carballeira, F. An ontology-driven decision support system for high-performance and cost-optimized design of complex railway portal frames. Expert Syst. Appl. 2012, 39, 8784-8792. [CrossRef]

116. Lee, J.S.; Lee, H.S.; Park, M.S.; Ji, S.H. A decision support system for super tall building development. Struct. Des. Tall Spec. Build. 2013, 22, 1230-1247. [CrossRef]

117. Ölçer, M.G.; Akyol, D.E. A MADM based decision support system for international contractor rating. J. Intell. Fuzzy Syst. 2014, 27, 2163-2175. [CrossRef]

118. Esmaelian, M.; Tavana, M.; Arteaga, F.J.S.; Mohammadi, S. A multicriteria spatial decision support system for solving emergency service station location problems. Int. J. Geogr. Inf. Sci. 2015, 29, 1187-1213. [CrossRef]

119. Pinheiro, P.R.; Tamanini, I.; da Filho FC, S.; de Filho MÂ, M.R. Applying Verbal Decision Analysis on the Choice of Materials to the Construction Process of Earth Dams. In Information Computing and Applications; Springer: Berlin/Heidelberg, Germany, 2010.

120. Banias, G.; Achillas, C.; Vlachokostas, C.; Moussiopoulos, N.; Tarsenis, S. Assessing multiple criteria for the optimal location of a construction and demolition waste management facility. Build. Environ. 2010, 45, 2317-2326. [CrossRef]

121. Wagatsuma, H. Hybrid Design Principles and Time Constants in the Construction of Brain-Based Robotics: A Real-Time Simulator of Oscillatory Neural Networks Interacting with the Real Environment via Robotic Devices. In Advances in Neuro-Information Processing; Springer: Berlin/Heidelberg, Germany, 2008.

122. Villa, F. Semantically driven meta-modelling: Automating model construction in an environmental decision support system for the assessment of ecosystem services flows. In Information Technologies in Environmental Engineering; Athanasiadis, D.I.N., Rizzoli, P.A.E., Mitkas, P.A., Gómez, P.D.I.J.M., Eds.; Springer: Berlin/Heidelberg, Germany, 2009.

123. Abdullahi, S.; Mahmud AR bin Pradhan, B. Spatial modelling of site suitability assessment for hospitals using geographical information system-based multicriteria approach at Qazvin city, Iran. Geocarto Int. 2014, 29, 164-184. [CrossRef]

124. Smith, R.; Ferrebee, E.; Ouyang, Y.; Roesler, J. Optimal Staging Area Locations and Material Recycling Strategies for Sustainable Highway Reconstruction. Comput. Aided Civ. Infrastruct. Eng. 2014, 29, 559-571. [CrossRef]

125. El-Haram, M.A.; Marenjak, S.; Horner, M.W. Development of a generic framework for collecting whole life cost data for the building industry. J. Qual. Maint. Eng. 2002, 8, 144-151. [CrossRef]

126. Petrovic-Lazarevic, S. The development of corporate social responsibility in the Australian construction industry. Constr. Manag. Econ. 2008, 26, 93-101. [CrossRef] 
127. Cheng, Y.M. An exploration into cost-influencing factors on construction projects. Int. J. Proj. Manag. 2014, 32, 850-860. [CrossRef]

128. Xu, Z.; Coors, V. Combining system dynamics model, GIS and 3D visualization in sustainability assessment of urban residential development. Build. Environ. 2012, 47, 272-287. [CrossRef]

129. Ju, H.; Yang, X.; Yu, H.; Li, T.; Yu, D.J.; Yang, J. Cost-sensitive rough set approach. Inf. Sci. 2016, 355, $282-298$. [CrossRef]

130. Zhang, L.; Wu, X.; Qin, Y.; Skibniewski, M.J.; Liu, W. Towards a Fuzzy Bayesian Network Based Approach for Safety Risk Analysis of Tunnel-Induced Pipeline Damage. Risk Anal. 2016, 36, 278-301. [CrossRef]

131. Chang, D.; Chen, C.H. Product concept evaluation and selection using data mining and domain ontology in a crowdsourcing environment. Adv. Eng. Inform. 2015, 29, 759-774. [CrossRef]

132. Lai, X.; Liu, J.; Georgiev, G. Low carbon technology integration innovation assessment index review based on rough set theory-an evidence from construction industry in China. J. Clean. Prod. 2016, 126, 88-96. [CrossRef]

133. Vostakolaee, E.S.; Amirshahi, B. Designing a DSS to explore cement mines using fuzzy neural networks. In Proceedings of the 2015 International Congress on Technology, Communication and Knowledge (ICTCK), Mashhad, Iran, 11-12 November 2015; pp. 209-212.

134. Gangolells, M.; Casals, M.; Forcada, N.; Roca, X.; Fuertes, A. Mitigating construction safety risks using prevention through design. J. Saf. Res. 2010, 41, 107-122. [CrossRef]

135. Fenz, S.; Heurix, J.; Neubauer, T.; Tjoa, A.M.; Ghiassi, N.; Pont, U. SEMERGY.net: Automatically identifying and optimizing energy-efficient building designs. Comput. Sci. Res. Dev. 2016, 31, 135-140. [CrossRef]

136. Chen, Z.; Li, H.; Kong, S.C.W.; Hong, J.; Xu, Q. E-commerce system simulation for construction and demolition waste exchange. Autom. Constr. 2006, 15, 706-718. [CrossRef]

137. Brychta, M.; Dubisch, F.; Stift, F.; Palensky, P. QUEEN 2014; A novel design flow and decision support tool for sustainable buildings. In Proceedings of the IECON 2010 36th Annual Conference on IEEE Industrial Electronics Society, Glendale, AZ, USA, 7-10 November 2010; pp. 2448-2453.

138. Imteaz, M.A.; Shanableh, A.; Rahman, A.; Ahsan, A. Optimisation of rainwater tank design from large roofs: A case study in Melbourne, Australia. Resour. Conserv. Recycl. 2011, 55, 1022-1029. [CrossRef]

139. Kripakaran, P.; Hall, B.; Gupta, A. A genetic algorithm for design of moment-resisting steel frames. Struct. Multidiscip. Optim. 2011, 44, 559-574. [CrossRef]

140. Cavieres, A.; Gentry, R.; Al-Haddad, T. Knowledge-based parametric tools for concrete masonry walls: Conceptual design and preliminary structural analysis. Autom. Constr. 2011, 20, 716-728. [CrossRef]

141. Li, C.H.; Yun, X.H.; Mao, H. Evaluation Modeling for Construction Safety Management with Multi-Criteria Decision Support System. Appl. Mech. Mater. 2011, 94, 2308-2312. [CrossRef]

142. El-Diraby, T.E.; Osman, H. A domain ontology for construction concepts in urban infrastructure products. Autom. Constr. 2011, 20, 1120-1132. [CrossRef]

143. Qi, H.; Altinakar, M.S. A GIS-based decision support system for integrated flood management under uncertainty with two dimensional numerical simulations. Environ. Model. Softw. 2011, 26, 817-821. [CrossRef]

144. Shen, W.; Hao, Q.; Xue, Y. A loosely coupled system integration approach for decision support in facility management and maintenance. Autom. Constr. 2012, 25, 41-48. [CrossRef]

145. Dawood, N.; Hobbs, B.; Akinsola, A.; Mallasi, Z. The Virtual Construction Site (VIRCON)-A Decision Support System for Construction Planning. In Proceedings of the CONVR 2000 Conference on Construction Applications of Virtual Reality, Middlesbrough, UK, 3-6 October 2000; pp. 17-29.

146. Mira da Silva, L.; Park, J.R.; Keatinge, J.D.H.; Pinto, P.A.I. A decision support system to improve planning and management in large irrigation schemes. Agric. Water Manag. 2001, 51, 187-201. [CrossRef]

147. Rahman, S.; Odeyinka, H.; Perera, S.; Bi, Y. Product-cost modelling approach for the development of a decision support system for optimal roofing material selection. Expert Syst. Appl. 2012, 39, 6857-6871. [CrossRef]

148. Fuertes, A.; Casals, M.; Gangolells, M.; Forcada, N.; Macarulla, M.; Roca, X. An Environmental Impact Causal Model for improving the environmental performance of construction processes. J. Clean. Prod. 2013, $52,425$. [CrossRef] 
149. Langer, W.H.; Lindsey, D.A.; Knepper, D.H., Jr. Geologic Information for Aggregate Resource Planning. In Deposit and Geoenvironmental Models for Resource Exploitation and Environmental Security; Fabbri, A.G., Gaál, G., McCammon, R.B., Eds.; Springer: Dordrecht, The Netherlands, 2002; Volume 80, pp. 135-149.

150. Wang, H.J.; Zhang, J.P.; Chau, K.W.; Anson, M. 4D dynamic management for construction planning and resource utilization. Autom. Constr. 2004, 13, 575-589. [CrossRef]

151. Kapliński, O. Development and usefulness of planning techniques and decision-making foundations on the example of construction enterprises in Poland. Ukio Technol. Ir. Ekon. Vystym. 2008, 14, 492-502.

152. Leitão, J.P.; Matos, J.S.; Gonçalves, A.B.; Matos, J.L. Contribution of Geographic Information Systems and location models to planning of wastewater systems. Water Sci. Technol. 2005, 52, 1-8. [CrossRef]

153. Bansal, V.K. Application of geographic information systems in construction safety planning. Int. J. Proj. Manag. 2011, 29, 66-77. [CrossRef]

154. Dawood, N.; Mallasi, Z. Construction Workspace Planning: Assignment and Analysis Utilizing 4D Visualization Technologies. Comput. Aided Civ. Infrastruct. Eng. 2006, 21, 498-513. [CrossRef]

155. Méxas, M.P.; Quelhas, O.L.G.; Costa, H.G. Prioritization of enterprise resource planning systems criteria: Focusing on construction industry. Int. J. Prod. Econ. 2012, 139, 340-350. [CrossRef]

156. Yan, M.R. Multi-criteria Decision Model for BOT Project Selection. In Modeling Risk Management in Sustainable Construction; Springer: Berlin/Heidelberg, Germany, 2011; pp. 123-129.

157. Kuo, Y.C.; Lu, S.T. Using fuzzy multiple criteria decision making approach to enhance risk assessment for metropolitan construction projects. Int. J. Proj. Manag. 2013, 31, 602-614. [CrossRef]

158. Eichholtz, P.; Kok, N.; Quigley, J.M. The Economics of Green Building. Rev. Econ. Stat. 2012, 95, 50. [CrossRef]

159. Amin Hosseini, S.M.; de la Fuente, A.; Pons, O. Multi-criteria decision-making method for assessing the sustainability of post-disaster temporary housing units technologies: A case study in Bam, 2003. Sustain. Cities Soc. 2016, 20, 38-51. [CrossRef]

160. De la Fuente, A.; Pons, O.; Josa, A.; Aguado, A. Multi-Criteria Decision Making in the sustainability assessment of sewerage pipe systems. J. Clean. Prod. 2016, 112, 4762-4770. [CrossRef]

161. Jang, W.; You, H.-W.; Han, S.H. Quantitative Decision Making Model for Carbon Reduction in Road Construction Projects Using Green Technologies. Sustainability 2015, 7, 11240-11259. [CrossRef]

162. Rasiulis, R.; Ustinovichius, L.; Vilutienè, T.; Popov, V. Decision model for selection of modernization measures: Public building case. J. Civ. Eng. Manag. 2016, 22, 124-133. [CrossRef]

163. Rathore, Z.; Radwan, A.; Elwakil, E. Framework to identify and evaluate the cause of conflicts within a Matrix organization in construction industry using fuzzy expert system. In Proceedings of the 2015 Annual Conference of the North American Fuzzy Information Processing Society (NAFIPS) Held Jointly with 2015 5th World Conference on Soft Computing (WConSC), Redmond, WA, USA, 17-19 August 2015; pp. 1-6. 